\title{
Why we need to know more about diversity among the globally mobile: A systematic literature review of non-traditional expatriate research and future research agenda for minority expatriates ${ }^{1}$
}

\section{Purpose}

The purpose of this article is to provide a systematic literature review of research on nontraditional expatriates (NTEs) and an agenda for future research.

\section{Approach}

The systematic literature review of NTEs 2010-2020 followed Moher et al's flow-chart approach to undertaking a systematic literature review and included research on various categories of NTEs.

\section{Findings}

The article explains how the author developed an interest in NTEs and provides a brief distillation of the author's research on NTEs and its key contributions. The article then presents the findings of the systematic literature review of NTEs and highlights the key aspects and contributions of this research. The article examines the strengths and weaknesses of the body of research, how it relates to global mobility research broadly, and presents some issues for future literature reviews.

\section{Originality}

The article is original in building on earlier examinations of NTEs to provide a systematic literature review of NTEs 2010-2020 and an extensive agenda for further research in the field.

\section{Research implications}

The article highlights the limited research undertaken on some types of NTEs and issues of construct definition. The article presents issues for future research on NTEs including: a wider range of NTEs; the impact of changing locations for NTEs; identity and intersectionality of NTEs; and methodological issues within NTE research. Moreover, the call for future research suggests the need for greater construct clarity including proposing a new term to define this group, namely, minority expatriates.

\section{Introduction}

In this article I provide a systematic literature review of extant research on non-traditional expatriates (NTEs) 2010-2020 and an agenda for future research of NTEs. NTEs have been in focus in practitioner publications as well as expatriate communities and support groups but there has been limited academic research exploring the diversity of NTEs. McNulty and

\footnotetext{
1 The author thanks David Watling (PhD candidate, Griffith University) for research assistance with literature searches.
}

The author thanks Professor Roxanne Bainbridge (Central Queensland University) for introducing the PRISMA diagram to the author when they collaborated on an earlier publication.

The author appreciates the commitment of the Expert Review Series Editors, Dr Yvonne Kallane and Dr Anthony Fee, in providing guidance throughout the writing of this paper. The author also appreciates the constructive and insightful suggestions of the anonymous reviewers. 
Hutchings (2016) wrote a (non-systematic) critical literature review on non-traditional expatriates (NTEs) to accompany a special issue in The International Journal of Human Resource Management in which they established the need for more research on this group of expatriates. In this current article I update the research that has been undertaken since McNulty and Hutchings' (2016) review. I explore the area for Journal of Global Mobility readers by further clarifying categories of the lesser studied NTEs, examining issues of construct definition in this area, and highlighting strengths and weaknesses of the body of research and how it broadly relates to global mobility research. I provide a further agenda for future research of this important and diverse group of globally mobile workers including suggesting that moving forward they are re-named minority expatriates.

\section{NTEs as a construct}

McNulty and Brewster (2017) noted there is limited construct definition about expatriates broadly. Guttormsen (2018) also noted issues with construct definition for NTEs specifically. Though NTEs are not new within the expatriate population overall, the research using the term NTEs is in its early stages, and thus, as a basis for reviewing the research that has been undertaken, it is important to understand how NTEs have been variously defined.

Some researchers have used the term NTEs in conversation, presentation, and in practitioner and academic publications, to refer to people who have a non-traditional assignment i.e. other than an organisationally-assigned long-term posting. For instance, people who self-initiated expatriation have been referred to as NTEs (Kang, Shen, and Benson, 2017) as have those taking short assignments (Salleh and Nankervis, 2015). However, though such research included the term NTE, the researchers did not specifically define NTEs.

McNulty (2014) defined NTEs (in corporate/business global mobility) as people with 'special' circumstances that standard global mobility policies typically do not address and differing from traditional expatriates in respect to: family composition; family challenges; family status; sexual orientation; and gender. McNulty and Hutchings (2016) defined NTEs by delineating assignment type (expatriation) from expatriate and referred to NTEs as people who work globally rather than the type of global work they undertake. McNulty and Hutchings (2016) further defined NTEs as including (albeit not limited to): female expatriates (including female breadwinner); single parent expatriates; lesbian, gay, bisexual and transgender (LGBT) expatriates; split family expatriates (where one partner, and perhaps also children, stay in one country while the other partner expatriates); expatriate families including children with disabilities or special needs and/or gifted children; expatriate families with children adopted 
overseas; and multigenerational expatriate families (e.g. including grandparents or other relatives); and blended expatriate families (e.g. step children). Guttormsen (2018), stated that NTEs have been variously considered in relation to the form of assignment they do internationally, or their experiences as individuals, or socio-biological characteristic/traits. Though fitting with McNulty and Hutchings' (2016) expatriate types, Guttormsen's focus on socio-biological characteristics/ traits was grouped into three categories, namely; relationshipfamilial relationships-sphere; relationship with children-sphere; and generation and age-sphere.

There are some limitations in how the NTE construct has been defined. First, whilst some researchers have defined NTEs as including a list of categories of people, NTEs have been defined in respect to what they are not i.e. not traditional expatriates. Though there is a concern in considering people in respect to what they are not (which implies an 'otherness') rather than focusing on what they are, this does address issues raised by McNulty and Brewster (2017) of the overlapping boundaries that occurs in defining expatriates more broadly. An associated issue is that that, like NTEs, there is variation in how traditional expatriates have been defined, and I concur with Guttormsen (2018) that they are ill-defined. Researchers have used the term traditional to refer to assigned expatriates (Cerdin and Brewster, 2014), expatriates from developed/western countries (Goxe and Paris, 2016), or older males in senior roles with accompanying (female) spouse and children (McNulty and Hutchings, 2016). The variations in the use of the term NTE likely partly results from variation in defining traditional expatriates, and more broadly as McNulty and Brewster (2017, p.35) suggested a "general assumption in most of the literature that 'we all know' who expatriates were" - or think we know who are traditional or non-traditional expatriates.

Second, McNulty and Hutchings (2016) mentioned using intersectionality theory (see Cho, Crenshaw and McCall, 2013) in future NTE research. However, intersectionality is an important aspect that has not been well addressed within the NTE research, which has tended to have been presented as studies of a category or group within a category of NTEs e.g women/female expatriates, LGBT expatriates. It seems likely that many people will fit into multiple NTE categories e.g. a person may be a transgender expatriate as well as in a blended expatriate family, a person may be a lesbian expatriate and a single parent of a gifted child, or a person may be non-binary and in a split family expatriate relationship. Thus, the limited consideration of intersectionality is a limitation in the NTE construct.

Third, some expatriates that researchers may categorise as NTEs may not think of themselves as being distinct from other expatriates and accordingly, may be more difficult for researchers to access and thus it may be difficult to fully capture who should be included within 
the NTE construct. Though researchers use the term NTE to define a group of expatriates that have not been well studied and consider that they are a smaller group among the traditional expatriates, caution must be used to avoid placing people into the category of 'other' from the perspective or those who are not part of their group (i.e. a researcher or 'traditional' expatriates). Such 'othering' can lead to stigmatising 'us' as the self (the researcher or the person/group who is not the focus of study) and 'them' (the group in focus) as others (see Staszak, 2020). Creation of such divisions is contrary to my intent herein in which I emphasise the importance of recognising NTEs in research rather than adding further to (potential) marginalisation. Moreover, researchers have tended to focus on homogeneity without enquiring into (or even recognising) aspects of individuals' gender or sexuality or family relationships; thus, resulting in NTEs being somewhat 'hidden' in research.

\section{NTEs as defined in this article}

Like McNulty and Hutchings (2016), I use the term NTEs within this article to refer to the people who work internationally and not the type of assignment they undertake. That is, the $\mathrm{E}$ in the acronym refers to being an expatriate and not expatriation/expatriating. NTEs, as I discuss them within this article, may self-initiate or be assigned to work globally in a short-term or long-term role, work in for-profit business organisations, government organisations, not-forprofit (NFP), or non-government organisations (NGOs) but what makes them an NTE is their individual or family situation.

I include within the term NTEs in this review categories of expatriates examined by McNulty and Hutchings (2016) with the addition of the category of age (younger expatriates as well as older/semi-retired expatriates). Though these categories also broadly agree with Guttormsen (2018)'s socio-biological characteristics/traits, unlike Guttormsen, I do not conflate split family relationships with single expatriates. Rather I make a definite distinction of single people being those that are not currently in any form of personal/romantic relationship whereas split family arrangements involve people who are currently partnered but physically separated internationally for work reasons. Thus, it should be noted that, in referring to relationship/family situation, I include in this definition people who are single and/or not currently in a personal partnership and categorise this as a relationship status. I also note that people's sexual orientation and/or gender might be considered separately from/not necessarily fit into a relationship categorisation.

In providing a definition of what I include within a categorisation of NTEs and making a stark distinction from traditional expatriates as being older males in senior roles with female 
spouses and children accompanying them on assignment, I address the need to ensure that there are clear boundaries around who is and who is not an NTE.

\section{Overview of the article}

In this article I commence with a distillation of my own research examining NTEs, and its key contributions. I then provide an overview of the process I utilised to conduct a systematic literature review on NTEs. I then review this literature on NTEs in respect to key themes examined within the literature from the search and its relevance for global mobility scholarship and practice and for readers of Journal of Global Mobility. I follow this with reflection on strengths and weaknesses across the NTE research. Then I examine some limitations of the research examined in the review. Finally, I present an agenda for further directions for this stream of research.

\section{Developing an understanding of issues for NTEs - an overview of my own research}

On reflection I always had an interest in the expatriates that had not been a major focus for other researchers. I commenced research in my early twenties with a $\mathrm{PhD}$ examining employment relations and human resource management (HRM) practices of multinational corporations (MNCs) operating in Asia. Whilst doing fieldwork in three countries in Asia, which included some interviews with Australian expatriate managers lasting more than two hours, I developed an interest in the people that lived and worked overseas as they managed local people in these organisations and experienced cross-cultural challenges in both work and non-work domains. I was one of a few who studied Australian expatriates whilst others were writing about North Americans and Europeans and, for many of these expatriates I first studied, whose lives were shaped by their international sojourns, it was their first such international exposure. As I expanded the industries and sectors of MNCs and countries of origins of expatriates I studied, I added the Middle East to an already established interest in Asia, and a focus on NTEs began to evolve.

In addition to researching in many countries internationally, I have been a visiting academic on multiple occasions in multiple locations in Asia, Europe, and North America what we might call a short-term expatriate - and whilst doing so I had increasing interest in the challenges and opportunities presented to the people who were less prevalent among the expatriates (or less researched!). I maintained academic distance in my research but there was an inherent curiosity that reflected my own experiences so, I did have, to some extent, a small insider insight into or shared identity with some of whom I researched (see Collins and 
McNulty, 2020). There had been a lot of research on the role of spouse/family in contributing to expatriate failure or, conversely, to supporting the expatriate to maintain an international assignment. Yet, I noted that there was much less consideration given to people that worked internationally for short- or long-term periods who did not fit the traditional expatriate mould of a male, working in a for-profit business organisation, and expatriating with a female spouse and children.

Among the significant number of publications that I have co-authored with colleagues on NTEs, the majority were about women expatriates. This research incorporated women from developed and developing economies, single and partnered women, and women working in business, government, non-government, and not-for-profit organisations. The research I conducted with colleagues on women expatriates commenced with examining western women expatriates living and working in developing economies and evolved into research on women from non-western and developing economies' attitudes to working internationally and then, critical reviews of the extant literature in the field.

The research on western women expatriates identified a range of key issues. I researched women expatriates working in China who felt that they did not have equal treatment to male colleagues and single women expatriates, specifically, did not have social support networks (Hutchings, French and Hatcher, 2008). I examined western women working in the United Arab Emirates (UAE) who did not report gender and cultural stereotyping at work, but they did suggest stereotyping occurred in the non-work context although this partly reflected how long they had been expatriates in the location and their interaction with locals (Hutchings, Michailova and Harrison, 2013). I also explored women military expatriates working in combat zones (Fisher, Hutchings and Pinto, 2015) who utilised coping strategies to deal with stressors in the work and intercultural context including support from family and friends and religious faith.

The research I undertook on women from developing economies identified that women from a range of Middle Eastern economies have managerial, international employment, and skills development opportunities primarily from non-government organisations and women's organisations (Hutchings, Metcalfe and Cooper, 2010); and Arab Middle Eastern women's expatriate opportunities rely on socio-cultural value change as well as secondments, short-term international assignment postings and cultural exchanges to other countries (Metcalfe, Hutchings and Cooper, 2009). A publication on Sri Lankan women (Hutchings, Samaratunge, $\mathrm{Lu}$ and Gamage, 2015) found women would consider expatriation when they had positive female role models and family/husband support, but they also expected to experience prejudice 
in host countries. The women also felt their opportunities were limited by gender discrimination in organisations and societal values that meant a primary responsibility to be a carer (wife, mother, daughter). A comparative study of Arab Middle Eastern and North American women that examined whether women's opportunities to work internationally were better facilitated by long assignments or short-term work (Hutchings, Lirio and Metcalfe, 2012). This study found the North American women preferred short-term international business travel as long-term work was difficult due to dual-career issues whereas for Arab women short-term international assignments and international business travel would be difficult given caring responsibilities, but long-term international assignments would provide family stability. It is important to note though that this study - or indeed some of my other research projects on women - only examined women, and the findings across these cultures may also have been relevant for men or other genders. In a recent article (Haak-Saheem, Hutchings and Brewster, 2021) I examined career choices and trajectories of women from Asian, Arab, and Western countries who self-initiate expatriation in the United Arab Emirates (UAE). This study identified that women's national grouping as well as their relationship status (married or single) had bearing on their career choices and that varying life stages and happenstance often played a more significant role in determining their career trajectories than specific career plans.

The interest I had in women expatriates resulted in publication of a co-edited research handbook on women in international management (Hutchings and Michailova, 2014a). This handbook was one of the first volumes to comprehensively examine the diversity of experiences, views and perceptions of women in international management encompassing women who manage and work in multinational corporations, local businesses, non-government organisations and not-for-profit organisations, and included women who were organisationallyassigned and self-initiated expatriates. This handbook also incorporated research on women from much more diverse areas of the globe than had previously been examined. The handbook included an introductory chapter (Hutchings and Michailova, 2014b) that reviewed past trends and identified emerging issues for women working internationally and called for more research on among others, single female expatriates, female expatriate volunteers, women expatriates in male-dominated industries, and women in international political roles.

The handbook was followed by developing a critical literature review on women expatriates (Hutchings and Michailova, 2017) which overviewed key themes and trends in the research and theories and methods used and identified theories that could be used in subsequent research. This book chapter also highlighted the need for more research on women expatriates from developing economies, women expatriates working in non-business organisations, and 
women expatriates in non-traditional families. An article critiqued the marginalised place of women in international business (Michailova and Hutchings, 2016) and suggested that there had been little consideration given to women (or gender) within international business research and research on women expatriates has tended to focus on western women in business organisations. This article called for greater consideration of gender broadly in the field and specifically with reference to non-western contexts and the structures through which gender is enacted.

Following this long-standing interest in one group of NTEs and reference to other types of NTEs in articles that were more ostensibly about expatriates' selection, training, and crosscultural experiences, in 2016 I co-published a special issue on NTEs which included a detailed, critical literature review of NTEs (McNulty and Hutchings, 2016). In this article, NTEs were defined and a range of NTEs across a spectrum of family situations were identified and examined which included: female expatriates; split family expatriates; lesbian, gay, bisexual and transgender expatriates; single parent expatriates; expatriate families with children with disabilities/special needs or gifted children; expatriates with overseas adopted children; multigenerational expatriate families; and blended expatriate families. Within this critical review mobility barriers and success factors for NTEs were identified which highlighted the need for the broader expatriate and global mobility literature to include samples that encompass the full and increasingly diverse range of people and families that choose to relocate internationally.

I have also extended my research into a wider range of NTEs. An article on lesbian and gay expatriates (McPhail, McNulty and Hutchings, 2016) concurred with limited earlier research in finding that lesbian and gay expatriates experience discrimination and stereotyping and may have limited organisational support and indeed may not be able to expatriate to some locations in which their relationship is illegal. The study did also identify that as expatriates, lesbian and gay people may achieve greater mobility through the legal and financial independence of their partnerships. I also developed an interest in split family expatriates (in which an expatriate works/lives in one country and their spouse and, sometimes, children live in another country). A chapter on this topic (Hutchings and McNulty, forthcoming) identified stressors and strains and changes to family dynamics and highlighted the importance of agreed actions and timelines at the outset and suggested the need for future research studying a wider range of family types who live in such arrangements.

Most recently, I researched older expatriates (Hutchings, Wilkinson and Brewster, 2020) in a study that examined academics who had retired or given up senior administrative 
responsibilities but who continued to work (often unpaid) which involved frequent international travel. These older academic international business travellers had a strong identification with occupation and varying reasons to continue working to an older age with most having an intent to continue working as long as possible with international trips for research and/or teaching and/or consulting involving up to six months per year. In highlighting the work lives of this group of previously un-researched older expatriates, the study highlighted the need for further research of the invested human capital of such older workers who maintain strong international personal work connections. The research also contributes to NTE literature in finding that some people self-fund their global mobility in undertaking unpaid work. The article also extends the NTE research that has largely focused on long-term expatriates by examining people working as short-term or frequent business traveller expatriates.

\section{Process for conducting the systematic literature review}

The process of undertaking this systematic literature review of NTEs involved searching for peer-reviewed publications (journal articles and book chapters). I am aware of other dissemination of research on NTEs through practitioner publications, (print and online) newspaper articles, individuals' personal websites, expatriate blogs and other forms of social media, and there may indeed be more information and support available through such forums. However, I excluded these from the search as the intent of this article was to focus solely on examining academic research.

I limited the search to publications from January 2010 until December 2020. The rationale was twofold. First, noting that research in international human resource management (IHRM) is no longer in its infancy and recent literature reviews have found most research on multinational enterprises including expatriation were published between 2000 and 2014 (Bonache and Festing, 2020), the selected time period coincided with when there had been most studies of people expatriating. Second, having researched NTEs since the early 2000s, I knew that whilst there was research on people that could be categorised as NTEs prior to 2010, there has been a significant expansion in the number of publications, and diversity of types of NTEs studied, in the last ten years. It is, however, important to note that there is a longer history of research in this area that was published pre-2010. Whilst not directly using the term NTEs, it is likely that people that can be categorised as such have been examined outside the field of business such as in research in anthropology, geography, sociology, international development studies (among others) and especially likely where those studies examined global employees in 
aid and other NFP organisations. However, I had a primary focus on research undertaken within the field of global mobility/IHRM.

This research in the global mobility/IHRM area has most particularly examined female expatriates; with a significant body of research giving particular attention to organisational, individual, and national barriers or deterrents to women's expatriation and analysis of their managerial and cultural fit when they did expatriate. Pre-2010 there was a limited amount of research on LGBT expatriates. There was also a limited amount of research pre-2010 on people in commuter roles in which one partner stayed in the home country whilst the 'expatriate' commuted regularly to one or more overseas locations. Other literature reviews reference some of this pre-2010 research and critique the field of research on NTEs (Guttormsen, 2018; McNulty and Hutchings, 2016).

An initial search was conducted using the terms non-trad* OR non trad AND expat*. The following databases were used to conduct the search:

- ABI/INFORM Global

- Australian Public Affairs Full Text (APAFT)

- EBSCO (Business Source Complete, Political Science Complete)

- $\quad$ Econlit (Ovid) [EBSCOhost]

- IBSS (International Bibliography of the Social Sciences) (CSA)

- Proquest

- PsycARTICLES

- PsycINFO (ProQuest Dialog)

- Social Sciences Citation Index (WoK)

- Social Services Abstracts (CSA)

- Sociological Abstracts (CSA)

The initial search found 342 publications (including 7 publications sourced from Google Scholar) produced in English. From this the following were excluded: dissertations and theses $(n=117)$, reports/non-academic $(n=5)$ and duplicates $(n=53)$. From this list of 167 another 115 were removed after identifying the titles showed no relevance to the research e.g. the titles referred to a very wide range of topics but were not related in any way to expatriates/expatriation and may have been found through the search because the word traditional was somewhere in the text. From the remaining 52 sources $(n=46$ journal articles and $n=6$ books/chapters) another 35 were excluded as having no relation to the topic and not 
even being about expatriates (but may have mentioned the words non-traditional or expatriate somewhere in the publication e.g. papers about international investment or expatriate art) and five were excluded because, whilst they were about expatriates and they used the term nontraditional expatriate, they were about assignment type (expatriation) rather than the expatriates. For instance, some of these articles examined people who had self-initiated an assignment and the authors were referring to these people as a non-traditional expatriate but the people in the sample included groups that did not meet the definition of NTE that I use in this article.

Thus, only 12 publications remained that were focused on NTEs as I have defined them. It was evident, as I had expected, that there were only a small number of articles/chapters that used the term NTEs as I defined it as covering particular categories of expatriates. As such, it was necessary to undertake a second search of the literature in which I could not rely just on the terms non-traditional and expatriate but needed to use search terms that related to people that I and others have previously defined as NTEs e.g. female expatriates, female expatriate as family breadwinner, single expatriates, single parent expatriates, LGBTIQA+ expatriates, split family expatriates, blended-family expatriates, multi-generational expatriate families or expatriates with accompanying family other than partner/children. Given that I had also recently written on older expatriates that were working post-retirement (Hutchings, Wilkinson and Brewster, 2020) and empty nesters were referred to by McNulty and Hutchings (2016) and age was also included in one of Guttormsen's (2018) categories, I added the retiree term to the search to identify this group of NTEs.

This second search found over 1200 publications, but almost all were on female/women expatriates. Though females/women are a majority of the world's population and they may be the majority of expatriates in some occupations such as low-status domestic workers (see (Haak-Saheem \& Brewster, 2017; Özçelik, Haak-Saheem, Brewster, \& McNulty, 2019) and some research has suggested they are better represented amongt SIEs (Andresen, Biemann, \& Pattie 2015; Muir, Wallace, \& McMurray, 2014; Tharenou, 2009), other research has suggested they are under-represented among expatriates overall (see Shortland, 2014). Whilst female/women expatriates are a significant part of the NTE cohort, they have been well studied (for literature reviews, see Altman and Shortland, 2008; Hutchings and Michailova, 2017; Salamin and Hannapi, 2014; Shortland, 2014) and I did not want to provide another review overwhelmingly focused on female/women expatriates. So, I decided to undertake a third search that excluded female/women expatriates to provide a review that would examine the NTEs that have not been previously well considered in academic literature. Thus, the third 
search (from which this literature review was developed) used the process which is described next.

The search was limited to publications from January 2010 until December 2020. The search terms needed to be present in either the title or abstract of the publication and the publications needed to be produced in English and be full publications. The terms used for this search included:

expat* OR

ex-pat*

AND

"non-trad*" OR

"non trad*" OR

"split family" OR

"LGBT*" OR

"lesbian" OR

"gay" OR

"single*parent" OR

"special need child*" OR

"gift* child*" OR

"overseas adop*" OR

"multigen*" OR

"multi-gen*" OR

"blend* family" OR

"status reversal" OR

"retire*"

The following databases were used to conduct the search:

- $\mathrm{ABI} / \mathrm{INFORM}$ Global

- EBSCO (Business Source Complete, Political Science Complete)

- EconLit

- IBSS (International Bibliography of the Social Sciences) (CSA)

- Proquest

- PsycARTICLES

- PsycINFO (ProQuest Dialog) 
- Social Science Citation Index

- Social Services Abstracts (CSA)

- Sociological Abstracts (CSA)

Additionally, a search was undertaken on Google Scholar for other academic articles/chapters using the key search words and an additional search was done on Google Scholar for the authors of the papers included from the database search. This produced three additional chapters and two journal articles. Figure 1 shows the PRISMA flow diagram (which is well utilised across disciplines) and details the process for including and excluding publications. The PRISMA diagram (see Moher et al., 2009) is beneficial for systematic literature reviews because it visually presents the review process in respect to steps undertaken including showing the number of publications found in the search and excluded through the various steps. Following the initial database and Google Scholar search, duplicate records were removed. From this record a preliminary screening was conducted in which some publications were removed because they were not in English, theses, or not relevant/related to the topic based on their title/abstract. At this point all the remaining full-text publications were reviewed and full-text articles were removed where they were not on the required topic e.g. publications in which the search term/s was somewhere in the abstract and/or title but the article was not actually about NTEs as I define them.

Articles/chapters found from the database search that were excluded included a) those that were not at all related such as articles on aspects of national HRM practice or international travel reflections or b) papers with one or more of the search terms but did not examine expatriates or expatriation experience e.g. studies of masculinity, sexuality, lesbian, gay, bisexual and transgender rights in a national context, or c) papers that did examine some aspect of expatriates/expatriation but did not focus specifically on the selected NTEs e.g. migration decisions, pensions/compensation/taxation, female/women expatriates. A few articles included the term non-traditional expatriates but used the term in relation to assignment type such as short-term assignments and thus were excluded for not meeting the criteria of this search. Also, within the broader expatriate/expatriation literature, some researchers include migrants with expatriates, and some use the terms interchangeably (and indeed some self-initiated expatriates may shift their status from temporary to permanent residents/citizens). However, within this review I only present research on expatriates who are expatriating for a fixed term or not-yetdetermined period, and this excludes people who have intent to move permanently. The final list of 23 publications is included in this review. 
[insert Figure 1 here]

\section{NTEs literature review}

As explained in the introduction and the search strategy presented above, most of the research on NTEs has examined female/women expatriates. The intent in this systematic literature review was to focus on other types of NTEs whose experience needs to be more fully explored. Figure 2 provides a summary of types of NTE expatriates discussed within this review.

[insert Figure 2 here]

\section{NTEs - a systematic review of the literature 2010-2020}

Table 1 lists the publications included in this systematic literature review. Like other systematic literature reviews, this review examines the publications for issues researched, background research or theories underpinning the research, methodological approaches, and data collected. Although the search was for publications 2010-2020 and available online when the search was conducted, one of the publications is referenced as 2021 and one is referenced as forthcoming because the publications had not been assigned their final publication date at the time of the search. Table 1 lists the included publications according to a) author/s, b) year of publication, c) journal or publisher (in the case of book chapters), d) Google Scholar citations (as at $30^{\text {th }}$ June 2021), e) country of employing institution of author/s, f) type/s of NTE examined, g) type of research - conceptual, literature review, qualitative, quantitative, or mixed method publication, h) cross-sectional or longitudinal data, i) data collected (where relevant), and $\mathrm{j}$ ) theory/ies or research referenced. The classifications d-j form the basis for the following review of the literature.

[insert Table 1 here]

\section{Citations}

As the research examined in this review covered only the last ten years, as would be expected given that citation numbers increase as publication age, the citation numbers (as of June 2021) are not very high for these publications (see Table 1). Journal articles have much higher citations than book chapters even when the chapters appear in books that are specifically about expatriates and, as would be expected, generally the higher citations (above 50) are for the older 
publications and publications from 2019 onwards have low or no citations. The most cited publications are those examining LGBT expatriates (although these are also generally older publications and the focus of most of the publications in the list). The other most cited publications examine a range of NTEs including a critical review of the area.

\section{Country of authors' institutional affiliation}

The 23 publications were authored by 30 researchers (although several of the those have been authors of no more than one NTE article and most of the research has been done by a few researchers who have published a range of articles/chapters on NTEs). The authors are based in 11 countries but, again if the authors of only one publication on NTEs are excluded, most of the research is from authors based in a few countries (Australia, Canada, USA, Singapore). Most of the research was conducted by authors based at universities in the developed world with the only exception being an article from a researcher in Hong Kong, Special Administrative Region of PRC, and an article where the lead author is based in UAE. Whilst the nationality (or original country of origin) of the authors is not known, the employing institutions generally reflect the dominance of research from English-speaking Anglo countries as has been noted in studies of authorship of expatriate research generally (Dabic, GonzalezLoureiro and Harvey, 2013). Though Asia is well represented among the author affiliation in general expatriate research, the NTE research has been well researched by authors in Singapore but only one other Asian country, namely, PRC. There is some research from other developed, western countries e.g. France, Greece, Ireland, Norway and there is one author based in the Middle East. None of the NTE publications were authored by researchers based in Africa, Central/Eastern Europe, or Latin America.

\section{Type/s of NTEs examined and issues identified}

Of the publications included in the review two examine a range of different types of NTEs, two are conceptual or critical literature reviews of the field of NTEs, 14 examine lesbian, gay, bisexual, transgender and intersex (LGBTI) expatriates, two examine family/relationship status and family needs, and three examine expatriates in particular age groups.

\section{Publications examining several types of NTEs}

As one of the first researchers to use the term NTEs, McNulty (2014; 2015) provided two publications examining several categories of NTEs. The first of these publications (McNulty, 2014) examined case studies of women as western female breadwinners in status-reversal 
(heterosexual partnership) expatriate families, single parent expatriates, split family expatriate families (where one partner lives in another country), and lesbian expatriates. Though female/women expatriates were excluded from this systematic literature review as having been well examined elsewhere in the literature, McNulty's (2014) article is included here as there was a notable contribution to the NTE research generally and to the global mobility literature in that McNulty (2014) presented a more encompassing view of expatriate family than had been erstwhile used in much of the academic or practitioner literature i.e. "married, defacto, live-in, or long-term partners of the opposite or same-sex, with or without children, with family members that reside in one or many locations; and legally separated or divorced (single) adults with children, with family members that reside in one or many locations". In discussing the challenges presented to these NTEs, McNulty (2014) suggested that common to these NTE families is lack of access to, and easy interaction with, other families in a similar situation.

McNulty (2015) then further examined single parent expatriates, split family expatriate families, lesbian expatriates and also explored expatriates with overseas adopted children. In examining the hyper-diversity of the NTE families though case studies of their lived experience, McNulty (2015:290) questioned whether traditional acculturation paradigms are appropriate for NTEs and personal factors affect acculturation and said "none of the participants believe that fitting in or assimilating, even within an expatriate community let alone the local population, is a requirement for successful acculturation, where the very nature of being non-traditional makes it near impossible to achieve anyway. Thus, their acculturation seems to rest more on the internal strength of the family unit or wider support network (both at home, and abroad if one exists) to help them through experiences that to outsiders are considered odd or strange (e.g., divorce, adoption, or living apart)". In this article, McNulty (2015) provided a foundation for further studies of NTEs in the global mobility literature by identifying 10 categories of NTEs. McNulty (2015) noted that there had been no academic research on most of the categories but highlighted that there had been a range of industry reports/practitioner publications that had begun to examine these new trends in global mobility.

\section{Conceptual or critical literature review papers on the field of NTE research}

McNulty and Hutchings (2016), following the earlier paper by McNulty (2015), which provided some initial construct definition around NTEs, provided a critical literature review. They defined NTEs as contrasting with the traditional expatriate that had been the focus of much of the stream of research on expatriates and was an older male, well-established in career, working in a for-profit business organisation, and expatriating with a (usually) non-working/trailing 
female spouse and children. McNulty and Hutchings (2016), though noting the increasing diversity of ways in which people are globally mobile including long-term assignments, shortterm and project-based assignments, global virtual teams and being organisationally-assigned or self-initiated to expatriate, deliberately contrasted assignment type (expatriation) from the expatriate in that their definition of NTE focused on the expatriate themselves and not the type of work that they undertook. McNulty and Hutchings (2016) defined an NTE on the basis of family composition (step-parent, blended, single-parent, split, overseas adoption, multigenerational), family needs (children with disabilities or special needs or gifted children), family status (single expatriates, accompanying family members besides children), sexual orientation (lesbian, gay, bisexual) and gender (e.g. female breadwinners with male trailing spouses, single female expatriates).

Importantly McNulty and Hutchings (2016) did suggest that there may be other groups of people who could be categorised as NTEs. They further noted the importance of understanding the experience of NTEs given the increasing diversity of family and relationships throughout the world and that the nuclear family does not account for all situations and not the predominance of extended family/community in many cultures. In their review, McNulty and Hutchings (2016) examined a range of NTEs including female expatriates, split family expatriates, LGBT expatriates, single parent expatriates, expatriate families with children with disabilities or special needs or gifted children, families with children adopted overseas, multigenerational expatriate families, and blended expatriate families. Though McNulty (2015) had included female/women expatriates as NTEs only where they were roles such as female breadwinner, McNulty and Hutchings (2016) examined female/women expatriates generally in recognising that working women expatriates were still underrepresented compared to male expatriates and thus could be considered NTEs. Importantly for global mobility researchers, McNulty and Hutchings (2016) provided an agenda for future research including construct definition, barriers for mobility for NTEs, and success factors for NTEs.

Building on this initial review of types of NTEs, Guttormsen (2018) provided a valuable contribution in addressing the need for greater construct clarity and noted that there had been a degree of homogeneity assumed about expatriates in extant research but that the term NTE had been used in publications that examined expatriates/individual and expatriation/assignment type. In referring to Bourdieu's notions of field and rationality and sociological theories regarding categorisation, Guttormsen (2018) proposed the need for a conceptualisation of NTEs but raised concerns that five underlying assumptions exist, namely: the concept of NTEs has a fixed, one-dimensional meaning; NTEs signify a separate typology of expatriates relevant for 
conceptualisation; non-traditionality of NTEs assumed to relate to unconventional aspects rather than signalling a distinct typology; and NTEs is a binary concept in relation to traditional expatriates; and the process of defining NTEs is neutral without implications on research design and policy-advice. Guttormsen (2018) made a valid point in highlighting that, within the literature, traditional expatriates as a construct have not been well defined and there are challenges with binaries given that someone might be defined as an NTE if he is gay but could equally be viewed as fitting within the traditional expatriate category of male and western. So, this suggests global mobility researchers need to question whether certain demographic characteristics place someone in a binary of traditional expatriate or NTE and, further, it is also important to consider an individual's own identity focus.

\section{Publications on LGBTI expatriates}

After female/women expatriates, the next most researched category of NTEs is lesbian, gay, and bisexual (LGB) expatriates. Though the acronym LGBTIQA+ covers lesbian, gay, bisexual, transgender, gender diverse, intersex, queer/questioning, asexual, and may also refer to non-binary and pansexual, within the NTE literature, researchers have primarily researched lesbian and gay expatriates and, to a lesser extent, bisexual expatriates. Notable across the LGBTI publications was that, though several of the publications had LGBT or LGBTI in their titles, most authors only made brief reference to transgender or intersex expatriates, and some noted that there was no research on these people's experiences as expatriates.

The first publication in this category was from Gedro (2010) who asserted that, at that time, there had been no research published on lesbian expatriates because lesbians were often indiscernible within the female population - or it might be questioned, that global mobility researchers had not then considered sexuality of participants in their research. Arguing that lesbians face both gender discrimination and sexual orientation discrimination, Gedro (2010: 395) said that the "absence of research about lesbian expatriate issues perpetuates their invisibility and marginalization in corporate ranks". In discussing career development, Gedro (2010) suggested three issues that would be of relevance for lesbian expatriates (which has been affirmed in later empirical research of LGB expatriates), namely: safety of the culture of the host country; (where partnered) the safety and appropriateness of bringing their partner on the international assignment; and (where closeted) they may need to come out of the closet to seek organisational assistance about safety of the host country and benefits/support for the partner. In referring to a 'lavender ceiling', similar to the glass ceiling for females/women, which is a tendency not to promote those in the sexual minority, Gedro (2010:396) highlighted there also 
being a global closet which is "the necessary negotiation of lesbian identity when traveling and working overseas" and considering and being considered for an international assignment.

Using the acronym LGBT and term sexual minority interchangeably, Gedro, Mizzi, Rocco, and van Loo (2013) presented auto-ethnographic stories of three of the authors (two of whom have been expatriates) to present issues of concern for lesbian, gay, bisexual and transgender (LGBT) expatriates and recommendations for LGBT expatriates and organisations engaging with expatriates. In presenting a table of issues and actions for employers and employees, Gedro et al. (2013) suggested four issues for awareness, namely: awareness of the challenges faced by sexual minorities when they relocate internationally; understanding of the complexity of the legal landscape internationally in respect to anti/discrimination; the importance of belonging for LGBT expatriates; and the complications of separation from or relocation with partners/family members.

Following Gedro's (2010) call for empirical research on LGBT expatriates, a range of publications were produced. Mizzi (2014: 296), who researched gay aid workers, highlighted concerns that organisations provided very little support, information or support for gay expatriates and suggested the need for intersectional, whole person inclusivity with online or in-person training within the context of LGBT-friendly workplaces avoiding heteronormative pre-departure orientation that "reduces the possibility of meaningful discussions around human diversity, particularly with regard to sexuality and gender identities, intersected with other identity markers". Mizzi's (2015) publication reflected on the study reported in the 2014 paper and another study to examine the experiences of gay expatriates moving from the global south and global north and highlighted, like other research, that global mobility came with two concerns, namely, safety and inclusion as priority and questioning the legitimacy of sexual orientation. Mizzi (2015) stressed that sexual orientation must be addressed at the organisational level by all levels of management and that awareness-raising and action planning are essential.

McPhail and colleagues produced five publications that form part of this review that examined various aspects of LGBT expatriate experience. McPhail and McNulty (2015), noting that LGBT employees may often opt for 'safer' career paths and thus self-select out of international assignment opportunities, examined lesbian and gay expatriates' perceptions of the duty of care that HRM should take for their wellbeing and safety whilst working in dangerous international locations. Highlighting the importance of context for safety and recognition that comfort or social values may be more telling for LGBT experience than legalities, McPhail and McNulty (2015) stressed the importance of not only individual actions 
to ensure safety but also the role of organisations in selecting assignees and providing support to them and their families. The latter point reflects concerns raised earlier by Mizzi (2014) about lack of support for LGBT expatriates through the selection and pre-departure process. McPhail, McNulty and Hutchings (2016) also addressed the issue of whether it is legal restrictions or social conventions that is most important for lesbian and gay expatriates and found that though expatriates' sexual minority status can be a disabler where they experience stigma and discrimination, they may also be enabled by their sexuality which provides more opportunities. Though, like other LGBT expatriate researchers, they noted the expatriates may receive limited organisational support, the experience of host country support was mixed.

McPhail and Fisher (2015) explored social media for gay and lesbian expatriates and how it is used as part of social capital for acculturation, and, as in earlier LGBT expatriate studies, found that duplicity occurs where an employee may not share knowledge of their sexual identity and orientation, and this is affected by organisational and country factors. Noting that most LGBTI expatriate research has focused only on gay and lesbian expatriates, McPhail (2017) summarised the extant literature at that point as examining: opportunities, barriers, and challenges; discrimination; duplicity (in or out); and being in dangerous locations. McPhail (2017) further said there has also been limited theoretical underpinning in the research and that which has been (or could be) done included: social capital theory; career anchors; acculturation; and heteronormativity. McNulty, McPhail, Inversi, Dundon and Nechanska (2018) examined the role of Employee-Resource Groups (ERGs) and allies for voice of LGBT expatriates (though the interviewees were only straight, gay or lesbian) and found how important it was to have informal social dialogues, how silence also says something about voice, and shallow depth in voice decision making. McNulty et al. 's (2018:851) study reinforced that LGBT expatriates still suffer discrimination in voice despite companies promoting expatriate diversity and inclusive practices such as ERGs and ally networks and argued "while ERGs and Allies were found to be useful voice mechanisms for global mobility among some companies in our study, there remains a clear gap in policy, the depth and scope of voice equity, risk management protocols, and silence outcomes".

Paisley and Tayar (2016) provided a conceptual framework to illustrate how the multiple identities of LGBT expatriates are adjusted according to organisational and national contexts during an international assignment. They explained that, for LGBT expatriates, moving internationally to a new cultural context "may lead to a new intersection point of their multiple identities. Multiple identities can be grouped broadly into self-identity which is how the person feels on the inside and identity expression which is how they disclose and outwardly 
express their identity to others. Identity distance represents the distance between each strand of identity as well as self-identity and identity expression. Identity distance will either contract or expand in response to new norms and expectations in the host country. As different strands of identity diverge, or self-identity and the expression of this identity become distant, internal conflict becomes more likely" (Paisley and Tayar, 2016: 771). Paisley and Tayar (2016) further suggested specific expatriate contexts (which are not one dimensional) will determine how acceptable is an LGBT expatriate's sexual orientation and/or gender, but although some may adapt their expression of identity, this will not be possible for all to hide - and the extent to which they may need to engage in divergent intersectionality may affect adaptation and productivity.

Kim and Von Glinow (2017a) presented interviews with four self-initiated gay and lesbian expatriates in which they had three key findings, which they developed in relation to social identity theory, namely: personal-level contexts, such as previous discrimination in the workplace due to individuals' sexual orientation impacts decisions to disclose when expatriating; organizational-level contexts in respect to diversity and diversity awareness affects decision to disclose when expatriating; and, country-level context in respect to attitudes towards lesbian and gay people/relationships affects decision to disclose when expatriating. In their book chapter, Kim and Von Glinow (2017b) examined the four gay and lesbian selfinitiated expatriates' experiences in respect to challenges/issues they faced, and importantly added to earlier research in examining perceptions of their contributions to the international assignments.

Building on earlier research on LGBT expatriates and issues previously raised about discrimination/stigma, Moeller and Maley's (2018) conceptual paper about identifying and managing stigmatisation of lesbian, gay and bisexual expatriates, suggested that hostility experienced in host countries arises from an incompatibility in values of the host country and the expatriates and the dissonance between the two value systems which leaves the expatriates needing to self-manage stigmas that are imposed on them both at work and outside the workplace. Importantly for global mobility researchers, Moeller and Maley (2018) highlighted the need to create understanding of legitimacy-building in international organisations to support lesbian, gay and bisexual expatriates' needs which recognise their (and their families') differences.

Referring to expatriate migrants, Suen (2021), examined the experiences of 13 lesbian and gay couples who moved to Hong Kong for temporary work in international organisations and examined issues surrounding applying to permanently stay. Suen's (2021: 14) paper 
recounted the case brought by one of the couples arguing against the Hong Kong government's differential treatment which provided different-sex couples but not their same-sex counterparts a dependent visa, and the ruling which overturned this which "the media as well as the LGBT NGOs in Hong Kong hailed it as an important victory for sexual minority rights in Hong Kong”. Suen's (2021) paper also examined an issue of broader importance for global mobility researchers in arguing agency of lesbian and gay expatriates impacting the local sexual context in that not only are they affected by the host country but they, in turn, can bring about change in the host country.

\section{$\underline{\text { Publications on other family/relationship expatriates }}$}

Though there is increasing diversity in family relationships and household composition internationally, IHRM research has previously only considered the experiences of family (and support provided by organisations when expatriating) in studies about spouse/partner and children.

Clark and Altman (2016) presented research from four cases of expatriates in Crete that involved multi-generational families and families of children with disabilities. Though the findings presented in this publication were based on four interviews, it formed part of longitudinal research in Crete, and among the self-initiated NTEs discussed were an empty nester, a generational family that moved between home and host country, an expatriate couple with an elderly parent, and an expatriate couple with an elderly parent and children with disabilities who then become involved in a split family expatriate situation. In focusing on the importance of multigenerational ties, Clark and Altman (2016) noted that their participants were neither assigned for a fixed period nor intending to stay indefinitely but their decisions reflected life stages and changing needs as they experience unpredictability, and their expatriation reflects flowing with life events as well as anchoring of their choosing.

Associated with changing life stages and the implications this can have for expatriation, is people who are split family expatriates. Historically there would have been many who were globally mobile who lived in split family expatriate situations such as where the 'expatriate' was in the military, international aid or humanitarian relief, or working as journalists, camera people and associated media support roles in conflict zones. Yet, though practitioner studies have suggested that the phenomenon of split family expatriates is increasing (Global Connection, 2014), it has received limited attention in the academic literature. Building on prior research by McNulty (2014; 2015), Hutchings and McNulty (forthcoming) drew on family systems theory and stress theory to examine challenges and opportunities presented to families 
in which an expatriate works/lives in one country and their spouse (and sometimes also children) live and work in another country (often but not necessarily a country of origin/citizenship). Through extended interviews conducted separately with each partner in two couples, Hutchings and McNulty (forthcoming) presented a range of issues that need to be considered by individuals and organisations before embarking on such arrangements. Hutchings and McNulty (forthcoming) contributed to global mobility research in suggesting that split family expatriation can be a valuable solution to dilemmas presented for dual career couples and allow one partner to undertake international work without disrupting other family members' careers, schooling, or lifestyle.

\section{Publications on age of expatriates}

Though age of expatriates had not been considered as a category of NTEs in an earlier critical literature review conducted by McNulty and Hutchings (2016), since that review there have been publications that have focused on expatriate age which researchers have defined as an NTE. Much of the early literature on SIEs focused on young people going on their first overseas experience/adventure which involved working in other countries, the migration research includes studies of older people that retire to other countries or change countries for preretirement work, some SIE literature refers to older expatriates, and across the expatriate literature researchers often use age as a demographic factor that is included in their analyses, but recent research has not given much consideration to expatriate age. Within this review, an article examined expatriates from Generation Y (Pereira et al., 2016) with Generation Y referring to people who are generally categorised as being born between 1980 and 1995. There was also a chapter in a book on expatiates examined millennial expatriates (Crowley-Henry and Collins, 2017), and an article examined older expatriates (Hutchings, Wilkinson and Brewster, 2020).

Pereira et al. (2016) examined young, highly qualified and mobile, Generation Y (Gen Y) knowledge workers and referred to them as a new category of NTEs that they named Yopatriates (people who are Generation Y, non-traditional expatriates) though they also referred elsewhere in their publication to NTEs as being an assignment type (such as SIEs). Suggesting that this group of NTEs were likely to undertake multiple short-term assignments, their analysis of the Yopatriates in a case study organisation in India found that, over three phases of the study, management were adapting to managing generational differences. They found these younger expatriates were more likely to rely on their own resources to find expatriate location information and the organisation used various strategies to better match 
recruitment, selection, and training with required global skill sets of the Yopatriates. Further, Pereira et al. (2016) found that adjustment was over a shorter duration with several rounds of the honeymoon and culture shock stages with deeper experiences of adjustment and mastery. Crowley-Henry and Collins (2017) examined millennial/generation Y expatriates (born around 1977-2005) and reinforced Pereira et al's (2016) assertion that there had been limited research in the field and, most of that was practitioner studies. They categorised it as falling into four areas, namely, influences, competencies, motivations, and expectations/potential and argued millennial expatriates have a preference to expatriate to western countries. Crowley-Henry and Collins (2017) further highlighted the need for flexible career paths for this group of expatriates (e.g. short-term, frequent travel) and suggested they are suitable for testing alternative global mobility strategies.

Hutchings, Wilkinson and Brewster (2020) studied academics from Australia, New Zealand and the UK who had retired (or given up senior administrative responsibilities) but continued to work with the work involving frequent short international trips for teaching, research or consulting. These short-term older expatriates are part of a growing group of people that continue to work past the usual retirement age but, rather than moving into employment in non-career areas, they remained in the work/careers that was central to their personal identity and undertook work that, in some cases, involved more international travel than when they had been in full-time work. Hutchings, Wilkinson, and Brewster's (2020) interviewees were primarily male, and the publication does not indicate any other demographic factors that would mean the interviewees could be categorised as NTEs but the focus on their older status/postretirement expatriate work is included as part of another category of NTEs of older expatriates as well as younger expatriates (Crowley-Henry and Collins, 2017; Pereira et al., 2016) that could be further examined in global mobility research.

\section{Methodological approaches}

Of the publications reviewed, six were conceptual or literature review chapters/articles (Gedro, 2010; Guttormsen, 2018; McNulty and Hutchings, 2016; McPhail, 2017; Moeller and Maley, 2018; Paisley and Tayar, 2016) and all the remaining publications presented findings from qualitative research (Clark and Altman, 2016; Crowley-Henry and Collins, 2017; Gedro et al., 2013; Hutchings and McNulty, forthcoming; Hutchings, Wilkinson and Brewster, 2020; Kim and Von Glinow, 2017a; Kim and Von Glinow, 2017b; McNulty, 2014; McNulty, 2015; McNulty et al., 2018; McPhail and Fisher, 2015; McPhail and McNulty, 2015; McPhail et al., 2016; Mizzi, 2014; Mizzi, 2015; Periera et al., 2017; Suen, 2021). Of the publications based on 
qualitative research, one of the publications referred to documentary analysis in addition to interviews (Mizzi, 2014), one publication was based on auto-ethnographic stories (Gedro et al., 2013), one publication included focus groups as well as interviews (Pereira et al, 2016), and two publications, though reporting interview data, had included a survey in an earlier stage of the research (Clark and Altman, 2016; Kim and Von Glinow, 2017a) whilst all the others were based on interviews only. The interviews across and within the publications were undertaken in a range of forms including in-person, by telephone, questions being sent/replied to by email, and various online tools including Skype.

Whilst most of the studies were cross-sectional, there were a few that involved longitudinal research with participants being interviewed multiple times (Clark and Altman, 2016; Periera et al., 2017; Suen, 2021) or stories reflecting on many years of experience (Gedro et al., 2013). As is typical for qualitative research, the sample sizes were small, ranging from projects involving auto-ethnographic stories from two people who had been expatriates, indepth interviews with four participants (Clark and Altman, 2016; Hutchings and McNulty, forthcoming; Kim and Von Glinow, 2017a; Kin and Von Glinow, 2017b; McNulty, 2014; McNulty, 2015) through to publications that involved more than 20 participants (Hutchings, Wilkinson and Brewster, 2020; McPhail and Fisher, 2015; Periera et al., 2017; Suen, 2021). Some publications also involved dyads of expatriate couples (Hutchings and McNulty, forthcoming; Suen, 2021).

\section{Theories and research used}

Some of the publications did not include specific theories but referred to prior research including issues of relevance for expatriates such as cross-cultural acculturation and adjustment (McNulty, 2015; Periera et al., 2017), global talent management research (McPhail and McNulty, 2015), and varying expatriate/expatriation research (McNulty and Hutchings, 2016). Others referred to research undertaken on the category of expatriate but examined in domestic/national research such as LGBT employees (Gedro, 2010; Gedro et al., 2013; McPhail, 2017; Mizzi, 2014; Mizzi 2015) and younger employees (McCrowley-Henry and Collins, 2017). Another publication, whilst not analysing their data against one specific theory, referred to theoretical concepts such as liquid modernity/fluidity and social ties/social networks (Clark and Altman, 2016).

Just as the broader expatriate literature includes much more reference to theory than in earlier years during which much of the research was atheoretical, the NTE literature examined in this review is also increasingly demonstrating engagement with specific theories. The 
theories underpinning the publications included: field/relationality theory (Guttormsen, 2018); family systems theory (McNulty, 2014); family systems theory and stress theory (Hutchings and McNulty, forthcoming); identity theory (Hutchings, Wilkinson and Brewster, 2020); social identity theory (Kim and Von Glinow, 2017b); social identity theory and self-categorisation theory (Kim and Von-Glinow, 2017a); stereotype threat theory (McNulty et al., 2018); social capital theory (McPhail and Fisher, 2015; McPhail et al., 2016); organisational legitimacy theory (Moeller and Maley, 2018); social constructivist intersectionality theory (Paisley and Tayar, 2016); and, framing theory (Suen, 2021).

\section{Strengths and weaknesses of the NTE literature}

The growing body of research on NTEs has been a welcome addition to the global mobility literature and provides a solid foundation for future research examining other NTEs who have not yet been examined (or well examined) in the literature and other areas for enquiry about the NTE experience. As demonstrated throughout the review, as the field of NTEs has developed, there have been efforts by researchers to address previously unanswered questions and to provide further insights and support for previously examined issues. There is much in the extant research on NTEs that should be of interest to readers of Journal of Global Mobility especially as organisations and researchers recognise the need to provide better understanding of the experiences and requirements of the diversity of people who are globally mobile but who may not have been well supported by organisations.

A further strength of the research is that of the 23 publications included in this review, almost half have a theoretical underpinning which, along with demonstrating research rigour, provides a solid body of research that demonstrates contribution to the wider expatriate/expatriation literature.

Some weaknesses in this body of the research can be noted. Excluding research on female/women expatriates which was not examined in this review, as shown in Figure 2, the extant NTE research can be categorised into three main areas (in descending order of quantity of research) as: LGBTI expatriates; family/relationship status expatriates; and younger or older expatriates. The research was presented in the review under these categories as generally the researchers took one dimension of an expatriate's gender/sexuality/family situation/age group as a focus of their research. It is important to note though that most NTEs will fall into a range of categories and a limitation of the emergent research is that it has not well considered such intersectionality. 
A further weakness in the extant research is that sample sizes are small. Though qualitative studies involving in-depth interviews with small numbers of participants are very appropriate for an emerging field of research and establishing issues for enquiry, the field does need to diversify the type of qualitative methods used to include more focus groups and documentary analysis. Other forms of qualitative research that would also be valuable for providing more insight into the phenomena for individual NTEs include narrative research, diary studies, textual analysis, and histories (which could document multi-assignment experiences). Further there need to be large scale, multi-country quantitative surveys in order to understand the numbers/percentage of global workers who may be categorised as NTEs and to provide more understanding of the support required and provided by organisations and individuals and other fora (e.g. expatriate communities). Moreover, though a few publications in the review referred to the NTEs they studied as being SIEs, a weakness across the publications is that most of the studies did not categorise the NTEs by expatriation type and, given the rapidly changing landscape of global mobility, it is important to understand how NTEs undertake global work (e.g. organisationally-assigned, self-initiated and recruited from the home country/in the host country, self-employed etc).

Further, though early conceptual papers/literature reviews (Guttormsen, 2018; McNulty and Hutchings, 2016) argued for better construct definition, some researchers are using the term NTE as I apply it herein as referring to expatriates (the people) whilst other researchers still use the term in articles about different forms of expatriation/global mobility (the assignment/work). Only nine of the publications included in this review used the term NTE and were found in an initial search using the term NTEs. Even within some of the publications in this review that refer to NTEs as the expatriate they examine, they also reference the term NTE as being forms of expatriation. Thus, a weakness is that some of the research examined in this review did not well relate the discussions to the concept of NTEs. Further, some publications had titles or abstracts that referred to groups that they did not examine i.e. LGBT mentioned in abstracts but only gay and lesbians examined in the research and discussed in the paper. Some of the articles could have better highlighted that they examined NTEs (or at least better articulated the need for the research on a group of expatriates that they explored that had not been well examined). Moreover, in their critical literature review which also served an introduction to a special issue on NTEs, McNulty and Hutchings (2016) noted that a first call for papers did not result in sufficient papers on the required topic and the second call also included many submissions that were about assignment type (e.g. self-initiated expatriation) and not the categories of NTEs that were delineated in the call for papers. It could be expected that the term NTE, as defined in this 
review, may not be well established until there is a larger body of research. In essence, the process of conducting this systematic literature review has shown that there are continuing issues with construct definition of the term NTEs.

Moreover, Haak-Saheem and Brewster (2017) suggested the need for more research on the lower status, 'hidden' expatriates, and recent research has provided more insight into working in non-business organisations (Fee and Gray, 2020; McNulty, Vance and Fisher, 2017). Yet, the limited number of publications in this review did not provide strong insight into where NTEs are employed and the type of work they undertake e.g. in which countries/regions of the world do they work?, are they working in business/government/non-government/not-forprofit organisations?, and are they in management/professional/skilled/semi-skilled/unskilled roles?

Apart from four publications (McPhail and McNulty, 2015; Mizzi, 2014; Mizzi, 2015; Suen, 2021) all the publications were chapters in books published by well-regarded international publishers or articles in journals that are listed as ABDC A/B and/or CABS 2/3 on the journal quality lists. The publications include several papers in Journal of Global Mobility and International Journal of Human Resource Management that take expatriates as one of their key focus areas. Of the four articles that were not on the ABDC A/B and/or CABS 2/3 lists, three (Mizzi, 2014; Mizzi, 2015; Suen, 2021) were published in journals outside the business discipline. So, the research in this emerging area has been published in quality outlets but it has not appeared in ABDC A* or CABS $4 * / 4$ ranked journals and undertaking research that has the theoretical grounding and sample sizes to warrant publication in the very highest ranked journals, should be a focus for the future of this field.

\section{Limitations of this review and issues to be considered for future literature reviews}

The research I examined in this review was delimited to academic journal articles and book chapters and though the research is small relative to the very large body of research on traditional expatriates, this does not mean that NTE numbers are small. As I noted in the introduction, it is likely that NTEs simply have not been the focus of academic research (perhaps due to difficulties in access including lack of identification) and/or their experiences have been subsumed under the research on traditional expatriates. Further, it is likely that there is more research in business and other disciplines that has explored people that I would categorise as NTEs but they were not found in this review because they did not include words that were used for the search terms e.g. papers that refer to people that relocate internationally for work while the family stays in the home county but they do not refer to them as expatriates 
or NTEs or split family expatriates. Thus, to fully understand the population of NTEs, subsequent academic research might also thoroughly examine relevant nonacademic/practitioner publications (e.g. BGRS, 2020; Mercer, 2021; Sante Fe Relocations, 2021), expatriate blogs, and websites of people and organisations that research and/or support NTEs, to highlight whether there are other issues that have not been examined in this article. It is important to note that Mercer (2021) also include other categories within global diversity and inclusion that were not examined as part of this review including thinking/personality style so a review of the practitioner literature may expand our understanding of how we define NTEs. Moreover, though this review focused on expatriates, there is research outside of (international) HRM that examines people that expatriate researchers would consider to be expatriates but that other researchers may refer to only as people working in other countries and such research was not found in this systematic literature review. Thus, future research might broaden the scope to include international work examined in the education, healthcare, and anthropology/sociology fields.

Collins (2019: 406) noted that, of the four journals that are aligned with the Academy of Human Resource Development, "less than $10 \%$ of our discipline's research explicitly focuses on the experiences of women, LGBTQ (lesbian, gay, bisexual, transgender, and queer) people, millennials, people of colour, or immigrants and expatriates". In the broader HRM literature there may have been greater attention given to the experiences of minority or non-traditional groups as part of a diversity agenda, but in the global mobility literature this underrepresentation of NTEs is still evident and, thus, I echo Collins' (2019) call for action to shift the research agenda to keep pace with the changing world. Moreover, future literature reviews might use a different term than NTEs given that the term has been used inconsistently by researchers and to ensure that the full diversity of people who are globally mobile are captured.

\section{A future research agenda}

Though researchers have provided definitions of NTEs (McNulty and Hutchings, 2016; Guttormsen, 2018), based on a systematic review of the NTE literature, I identified that there are groups of people that have not been considered within these definitions and warrant examination in future research. Figure 3 provides a more complete list of categories of people that could be considered NTEs in that they have not expatriated (or been studied within the expatriate literature) to the same extent as traditional expatriates. I add to the previously listed categories (Guttormsen, 2018; McNulty and Hutchings, 2016) people with disabilities, disease and illness, and people's religions and spiritual orientation. 
In the following paragraphs I detail some types of, and issues for, NTEs for future research. The future research agenda is presented as follows. First, I suggest there should be future research related to particular groups of NTEs that have not been (well) examined (expatriates with health conditions/issues, expatriates with disabilities, LGBTIQA+ expatriates, age demographics, under-researched countries, expatriates' religious beliefs). Second, I highlight the need for future research on NTEs in respect to changing locations (migration/SIEs, repatriation). Third, I argue for more research on identity of NTEs (intersectionality, changing identity within and across assignments). Fourth, I recommend more methodological approaches to studying NTEs (longitudinal studies, direct comparisons with traditional expatriates). Fifth, as I explained in the introduction to the article and commentary on weaknesses in the literature, there is need for greater construct clarity and this is highlighted as an issue for future research. Herein, consideration is given specifically to the NTE experience, but it should also be noted that, though the importance of organisational support has been highlighted in some earlier research in this area (e.g. McNulty and Hutchings, 2016), there is need for more attention to be given to outlining organisational policy to more fully support the diversity of expatriates. Such research could examine the support NTE expatriates receive (or require) from organisations and the challenges they may experience expatriating to contexts where there is limited infrastructure or social support or social stigma/discrimination that may impact on them more than may occur for traditional expatriates.

[insert Figure 3 here]

\section{Particular groups of NTEs}

First, the recent situation of the Covid-19 pandemic has brought to the forefront of attention of many employers and workers that health and safety risks associated with working across countries goes beyond being in specific dangerous situations such as war and conflict zones or areas of high crime or terrorism locations (see Faeth and Kittler, 2020; Pinto, Bader and Schuster, 2017) and highlights that other health issues transcend borders (De Cieri and Lazarova, 2020). Though all international workers may be at risk from health crises such as viruses, greater risk is posed to those who undertake frequent international travel in their roles. Caligiuri, De Cieri, Minbaeva and Verbeke (2020) suggested there is increasing working (and leading) at a distance/virtually and managing with uncertainty and there may be declines in international assignments in coming years. Even if expatriation, in its myriad forms, returns to more typical levels, there may be some people that self-select out of international work 
opportunities due to potential health risks. Those who choose not to expatriate may include categories of NTEs such as expatriates with disabilities and pre-existing health conditions; thus, meaning less diversity among the expatriate population globally. As De Cieri and Lazarova (2020) noted, there has been more discussion about health and safety concerns for global employees outside the business discipline, and I would suggest that there is much more need for business research focused on groups of global employees who may face greater health and safety risks than others. Thus, future research might examine issues around declining numbers of NTEs (or groups of NTEs) due to health conditions and implications of such for organisational diversity in international operations.

Second, though extant research has examined NTEs who expatriate with children who have disabilities, there is need for future research to examine expatriates with disabilities including physical disabilities, chronic illnesses, and psycho-social disabilities including mental illness and mental health issues. Such research could examine the challenges they may experience expatriating to contexts where there is limited infrastructure or social support or social stigma/discrimination against people with disabilities. Research has examined children in international schools (many of whom are children of expatriates) and has identified that some of these schools may have selective admissions requirements (and cater to 'gifted' children) whilst others may have policies precluding students with disordered behaviour and/or learning difficulties and/or special needs or cater only to children with mild learning disabilities (Shaklee, 2007). However, we know little about how expatriates with learning disabilities experience global mobility. Thus, future research could examine whether expatriates with learning disabilities identify, and how they experience living in cultural contexts that are more of less supportive of their needs than their home country.

Third, there has been a stream of research about LGBTIQA+ expatriates, but most of this research has examined lesbian and/or gay expatriates. There is need to understand (or more fully understand) how bisexual, pansexual, transgender, non-binary, intersex and queer people experience expatriation, and the challenges and discrimination they may face in certain locations globally. Moreover, future research could examine people who define themselves as A+ who some may include under a definition of single in relationship status but who may not categorise themselves as such and may be partnered. It is important to understand how people across the full spectrum of sexual orientations experience expatriation, and especially in some locations where there are stereotypes and discrimination against people who are not heterosexual and married after a certain age. Kraimer, Bolino and Mead (2016) suggested there was need for research on gender differences in willingness to travel internationally for short- 
term regular business. I suggest that there is need for research that examines whether LGBTIQA+ people prefer to undertake long-term or short-term assignments or other forms of global mobility such as international project work, and what factors motivate such choices.

Fourth, it is acknowledged that NTEs in a particular age group could also be considered as traditional expatriates in that they may also fit into that demographic e.g. older male or younger male with a trailing (female) spouse. As people increasingly expatriate at a younger age, and, as people work later in their lives and retire and then come out of retirement to return to work, older expatriates are also likely not so much of a minority. However, as other general HRM research has found that younger workers and older workers may have different ways of working and require different individualised HRM practices (Bal and Dorenbosch, 2015), this suggests that NTE age groups should be better explored in future research.

Fifth, though there has been increasing research on expatriates who relocate from developing countries (either to developed or other developing countries) and may relocate to work in developed world multinationals or the increasingly examined developing world multinationals, much of the research on NTEs has examined people who are working in countries that have also been well examined in the broader expatriate/expatriation literature (see McNulty and Hutchings, 2016). Thus, I concur with Guttormsen (2018) that there is need for more research on the representation, and experience, of NTEs in other less examined locations. Future research could examine NTEs relocating from (or to and within) Africa, Asia-Pacific (outside of Northeast and Southeast Asia), Central Eastern Europe, Latin America, and the Middle East. Such research could examine the extent to which culture and ethnicity impact on expatriate experience.

Sixth, research has increasingly examined expatriates that work outside the business/forprofit sector in government, non-government, and not-for-profit organisations such as in the military (Fisher, Hutchings and Pinto, 2015) as development volunteers (Fee and Gray, 2020), and aid workers (see chapters in McNulty and Selmer, 2017). However, there is need to understand how NTEs specifically experience expatriation in non-government, government, and not-for-profit organisations compared to business organisations. Moreover, though research has examined religious missionaries (McNulty, Vance and Fisher, 2017), future NTE research could examine how individuals' religious or non-religious or spiritual beliefs (as part of culture and ethnicity more broadly) impact on their experience as expatriates in business, government and secular not-for-profit organisations.

\section{Impact of changing locations for NTES}


Seventh, though migration studies (generally examined in disciplines such as geography and sociology) were once considered as distinct from expatriate/expatriation research, in recent years the global mobility literature has increasingly examined migration. There is some crossover between self-initiated expatriation with its open-dated intention which may mean individuals ultimately become migrants or permanent residents. Yet, within this literature there has been very limited reference to NTE migration. The research that has examined lifestyle migration or retiree migration (e.g. Benson, 2010; Butler, 2013; Emard and Nelson, 2020) (with some of the latter group still being involved in part-time paid work) could be expanded to include studies of specific groups of NTEs. For example, research could explore. LGBTIQA+ expatriates and their experiences of lifestyle migration, such as in relation to cultural values of the nation in which they reside and work and implications for adjustment and intercultural effectiveness. Moreover, as someone may be an NTE and an SIE, there is need for future research to examine the issues that these people may experience and if they have additional challenges (such as discrimination, safety). Further, though culturally the definition of family varies markedly, some countries do not provide accompanying visas for other than nuclear family members to relocate with an expatriate (e.g. O’Neil, 2016). Thus, future research might examine whether expatriates' career opportunities are affected by not being able to move countries due to not being allowed to bring elderly family members or family with disabilities for whom they provide care.

Eighth, though recent research has considered repatriation from a host country to retire in the home country (Rowson, 2015), the literature on NTEs has not examined NTEs' repatriation experience or, in particular, repatriating to retire (some of whom will still be engaged in part-time work either paid or volunteer, career-related or otherwise). Examination of the experience of NTEs when repatriating is warranted e.g. what is the experience of LGBTIQA+ people who were 'out' in the host country but may need to disclose their sexuality or gender when returning to their home country and being with family and friends who were not aware of their identity?, what re-adjustment challenges do repatriating NTEs' have in retiring to the home country in respect to changed (or lack of) support or affordability of support for an expatriate that has disabilities, or their children who have disabilities, or for their elderly family members? Consideration could also be given to impacts on family relationships when expatriates change their type of global mobility, such as reducing the amount of work they do to semi-retirement or when they no longer travel as frequently for work. For example, though research has considered impacts on the family when someone undertakes international travel in various forms of global mobility (Mutter and Thorn, 2019), it would be valuable to explore how 
family dynamics are affected by an expatriate reducing the amount of international travel they undertake.

\section{Identity and NTEs}

Ninth, the majority of the research on NTEs has focused on one type of NTE or one aspect of a person's identity e.g. gender or sexuality. However, people have a range of attributes (e.g. gender, ethnicity, disabilities, age), and these attributes intersect and have implications for their life and work experiences and opportunities they have in work and other domains (see Collins, 2015; Crenshaw, 1989). Thus, supporting the earlier argument by McNulty and Hutchings (2016) I suggest that there is still need for future research to explore intersectionality of NTEs, such as, for instance, the experience of a gay men who has a disability and is of a marginalised religious group.

Tenth, it is important for future research to consider that people will have different experiences across assignments and that peoples' circumstances and identity may also change within and across assignments. For instance, within an assignment or across assignments, someone may fall into the category of an NTE but then no longer be an NTE, such as in the case of someone who affirms their gender or a person's children leaving home and they are no longer a single parent expatriate. A gay couple with children may be able to expatriate and cohabit in one location but then may not be able to move together as a family unit to another country with laws that prevent them from co-habiting or for a gay partner to have a work permit/visa. Moreover, an individual's own identity and challenges in moving from one life stage to another could be researched in respect to what they have learnt from being an NTE and how this knowledge could be valuable to an organisation as NTEs work through (perhaps multiple, varying) assignments.

\section{Methodological issues in researching NTEs}

Eleventh, there are methodological issues that need to be addressed in future research on NTEs. Within the research on NTEs, most empirical studies have been cross-sectional. With the exception of research on female expatriates which has been extensively examined since the late 1980s, there is limited research on other NTEs and thus cross-sectional studies have their value in drawing attention to the experience of groups of expatriates who have not been previously explored. Moving forward there is need for longitudinal studies that consider whether NTEs have changing experiences in their career trajectories. As also noted in the section of the review that mentioned weaknesses of the extant research, future research needs to include large scale 
quantitative studies and much more diversity in qualitative approaches including narrative, diary and historical studies as well as textual analysis.

Twelfth, the extant research on NTEs has tended to focus on their experiences without directly comparing them with the traditional expatriates who are a majority. Future research needs to undertake these direct comparisons of NTEs with traditional expatriates to understand the unique situation of NTEs more fully. As part of this broader agenda, researchers need to not only better understand who comprises the NTE cohort but how they may differ across countries i.e. whether the experience of being in a minority within the overall expatriate cohort differs because of local contextual factors such as legislation, political environment and socio-cultural values.

\section{Construct clarity}

Finally, future research should address the need for greater construct clarity. In this article I used the term NTEs as this had been used in earlier research (Guttormsen, 2018; McNulty, 2014; McNulty \& Hutchings, 2016) to refer to the group of people that I also categorised and examined as NTEs. However, as I explained in the introduction and section on weaknesses of the literature examined in this article, there are only a small number of articles that use the term NTE and the term has not been used consistently. Though some researchers have used the term as I have herein to refer to groups of expatriates who have not been as prevalent among globally mobile workers as traditional expatriates, other researchers have used the term to refer to forms of expatriation that are not organisational-initiated and/or long-term. Even since the publication of articles using the term NTEs, other researchers have not used this term in articles examining expatriates that have been classified as NTEs (e.g. female/women expatriates, LGBTIQA+ expatriates etc) and thus, there are potentially many more articles that have examined NTEs but were not found in the systematic literature review because they did not refer to NTEs or use any of the search terms in their articles. Also, as both Guttormsen (2018) and I noted earlier, a further issue with construct clarity is that NTEs are defined by what they are not - a traditional expatriate - but there is also an issue of construct clarity around what is a traditional expatriate. Further, though the term non-traditional has been used to refer to people who have not been so prevalent historically among expatriates, some people that have been defined as NTEs may not identify as non-traditional or 'other' and being categorised as such may cause offense. As researching NTEs has been in the spirit of inclusion and examining the diversity of expatriates internationally, it is important that this is also reflected in the terminology used. Thus, given the term NTEs is relatively new and has not yet been well established in the global mobility 
literature, it seems appropriate to suggest another term could be used as this area of research develops.

A term that might be used by future researchers is minority expatriates. The rationale for such is twofold. First, the people that have been categorised as NTEs are a minority among the expatriate community and can be contrasted against the people that comprise the majority expatriates. If groups of minority expatriates moved from having minority status to being among the expatriate majority, they can be moved from the classification of minority. Thus, this term ensures that there is a distinct boundary around what constitutes a minority expatriate. Second, apart from females/women and people of some religious groups, the categories of NTEs explored in this article (see Figure 2) or more extensive categories of NTEs that could be explored in future research (see Figure 3) are also minorities within a domestic/national context. Thus, this term also has the benefit of allowing for examination of minority expatriates' experiences in reference to the experience of such minorities as considered in general HRM and management literature. Sparkman (2019) said that research streams in (diversity) management indicate the continuing link between HRM policies and difference-focused practices as drivers for diversity and inclusion. As such, there is need for research on the minority expatriates that transcends the boundaries between global mobility research and general HRM research (and indeed, other non-business disciplines).

\section{References}

Altman, Y. and Shortland, S. (2008), "Women and international assignments: Taking stock a 25-year review", Human Resource Management, Vol. 47 No. 2, pp.199-216.

Andresen, M., Biemann, T., and Pattie, M.W. (2015), "What makes them move abroad? Reviewing and exploring differences between self-initiated and assigned expatriation", International Journal of Human Resource Management, Vol. 26 No. 2, pp. 932-947.

Bal, P.M. and Dorenbosch, L. (2015), “Age-related differences in the relations between individualised HRM and organisational performance: A large scale employer survey", Human Resource Management Journal, Vol. 25 No. 1, pp. 41-61.

Benson, M.C. (2010), "The context and trajectory of lifestyle migration: The case of the British residents of Southwest France”, European Societies, Vol. 12 No. 2, pp.45-64. 
Bonache, J., and Festing, M. (2020), "Research paradigms in international human resource management: An epistemological systematisation of the field", German Journal of Human Resource Management, Vol. 34, No 2, pp. 99-123.

Brookfield Global Relocation Services (BGRS) (2020), Talent Mobility Trends 2020, available at https://www.bgrs.com/talent-mobility-trends/, accessed $11^{\text {th }}$ January 2021.

Butler, G. and Richardson, S. (2013), "Working to travel and long-term career dilemmas: Experiences of Western lifestyle migrants in Malaysia”, Tourist Studies, Vol. 13 No. 3, pp.251267.

Caligiuri, P., De Cieri, H., Minbaeva, D., Verbeke, A., and Zimmermann, A. (2020), "International HRM insights for navigating the COVID-19 pandemic: Implications for future research and practice", Journal of International Business Studies, Vol. 2, pp. 1-17, doi: 10.1057/s41267-020-00335-9

Cerdin, J-L., and Brewster, C. (2014), "Talent management and expatriation: Bridging two streams of research and practice”, Journal of World Business, Vol. 49 Issue 1, pp. 245-252.

Cho, S., Crenshaw, K.W., and McCall, L. (2013), "Toward a Field of Intersectionality Studies: Theory, Applications, and Praxis", Signs: Journal of Women in Culture and Society, Vol. 38 No. 4, pp. 785-810.

Clark, D. and Altman, Y. (2015), "Home, family and the self-initiated expatriate experience: Living with uncertainty, complexity and change", Mäkelä, L. and Suutari, V. (Ed.), Work and Family Interface in the International Career Context, Springer, Charm. pp.139-57.

Clark, D. and Altman, Y. (2016), "In the age of 'liquid modernity: Self-initiated expatriates in Crete, their multi-generational families and the community", The International Journal of Human Resource Management, Vol. 27 No. 7, pp.729-743.

Collins, H. and McNulty, Y. (2020), "Insider status: (Re)framing researcher positionality in international human resource management studies", German Journal of Human Resource Management, Vol. 34 No. 2, pp.202-227. 
Collins, P.H. (2015), “Intersectionality's definitional dilemmas", Annual Review of Sociology, Vol. 41, pp. 1-20

Crenshaw, K. (1989), "Demarginalizing the intersection of race and sex: A black feminist critique of antidiscrimination doctrine, feminist theory and antiracist politics", The University of Chicago Legal Forum, Vol. 1, pp. 139-167.

Crowley-Henry, M., and Collins, M. (2017), "Millennial expatriates”, McNulty, Y. and Selmer, J. (Eds.), Research Handbook of Expatriates, Edward Elgar, Cheltenham, pp.261-275.

Dabic, M., González-Loureiro, M. and Harvey, M. (2015), "Evolving research on expatriates: What is 'known' after four decades (1970-2012)", The International Journal of Human Resource Management, Vol. 26, No. 3, pp. 316-337.

De Cieri, H. and Lazarova, M. (2020), "Your health and safety is of utmost importance to us": A review of research on the occupational health and safety of international employees", Human Resource Management Review, https://doi.org/10.1016/j.hrmr.2020.100790

Emard, K. and Nelson, L. (2020), "Geographies of global lifestyle migration: Towards an anticolonial approach" Progress in Human Geography, Doi: 10.1177/0309132520957723, pp.1-21.

Faeth, P.C. and Kittler, M.G. (2020), "Expatriate management in hostile environments from a multi-stakeholder perspective - A systematic review", Journal of Global Mobility, Vol. 8 No. $1, \mathrm{pp} .1-24$.

Fee, A. and Gray, S.L. (2020), "Perceived organisational support and performance: The case of expatriate development volunteers in complex multi-stakeholder employment relationships", The International Journal of Human Resource Management, https://doi.org/10.1080/09585192.2020.1745864 
Fisher, K., Hutchings, K., and Pinto, L.H.F. (2015), "Pioneers across war zones: The lived acculturation experiences of US female military expatriates", International Journal of Intercultural Relations, Vol. 49, pp. 265-277.

Gedro, J. (2010), “The lavender ceiling atop the global closet: Human resource development and lesbian expatriates", Human Resource Development Review, Vol. 9 No. 4, pp. 385-404.

Gedro, J., Mizzi, R.C., Rocco, T.S. and van Loo, J. (2013), “Going global: Professional mobility and concerns for LGBT workers", Human Resource Development International, Vol. 16, pp.282-297.

Global Connection. Expat Partner Support. (2013), "Split families on the rise", available at https://www.global-connection.info/hr-articles/split-families-on-the-rise/, accessed $13^{\text {th }}$ July 2021.

Goxe, F., and Paris, M. (2016), "Travelling through the class ceiling? Social mobility of 'traditional' and 'new' expatriates”, International Journal of Cross Cultural Management, Vol. 16 No. 2, pp. 171-189.

Guttormsen D.S.A. (2018), "Does the 'non-traditional expatriate' exist? A critical exploration of new expatriation categories", Scandinavian Journal of Management, Vol. 34 No. 3, pp. 233244.

Haak-Saheem, W., and Brewster, C. (2017), “'Hidden’ expatriates: International mobility in the United Arab Emirtes as a challenge to current understanding of expatriation". Human Resource Management Journal, Vol. 27 No. 3, pp.423-439.

Haak-Saheem, W., Hutchings, K. and Brewster, C. (2021), "Swimming ahead or treading water? Disaggregating the career trajectories of women self-initiated expatriates", British Journal of Management, doi.org/10.1111/1467-8551.12465 
Hutchings, K., French, E. and Hatcher, T. (2008), "Lament of the ignored expatriate: An examination of organisational and social network support for female expatriates in China", Equal Opportunities International, Vol. 27 No. 4, pp. 372-391.

Hutchings, K., Lirio, P. and Metcalfe, B.D. (2012), “Gender, globalisation and development: A re-evaluation of the nature of women's global work", The International Journal of Human Resource Management, Vol. 23 No. 9, pp.1763-1787.

Hutchings, K. and McNulty, Y. (forthcoming), "Split family expatriation: Perspectives from expatriates and their career spouses", McNulty, Y., Collins, H. and Mutter, J (Eds). Research Handbook of Global Families Edward Elgar, Cheltenham, available at https://www.researchgate.net/profile/Yvonne_Mcnulty3/publication/324387157_Split_family _expatriation_Perspectives_from_expatriates_and_their_career_spouses/links/5acc2877aca27 2abdc64b680/Split-family-expatriation-Perspectives-from-expatriates-and-their-careerspouses.pdf, accessed $11^{\text {th }}$ January 2021.

Hutchings, K., Metcalfe, B. and Cooper, B. (2010), “Exploring Middle Eastern women's perceptions of barriers to, and facilitators of, international management opportunities", The International Journal of Human Resource Management, Vol. 21 No. 1, pp. 61-83.

Hutchings, K. and Michailova, S. (Eds.). (2014a), Research Handbook on Women in International Management, Edward Elgar, Cheltenham.

Hutchings, K. and Michailova, S. (2014b), "Women in international management: Reviewing past trends and identifying emerging and future issues", Hutchings, K. and Michailova, S. (Eds.), Research Handbook on Women in International Management, Edward Elgar, Cheltenham, pp. 3-17.

Hutchings, K. and Michailova, S. (2017), "Female expatriates: Towards a more inclusive view", McNulty, Y. and Selmer, J. (Eds.), Research Handbook of Expatriates, Edward Elgar, Cheltenham, pp.241-260. 
Hutchings, K., Michailova, S. and Harrison, E. (2013), "Neither ghettoed nor cosmopolitan: A study of western women's perceptions of gender and cultural stereotyping in the United Arab Emirates”, Management International Review, Vol. 53 No. 2, pp. 291-318.

Hutchings, K., Samaratunge, R., Lu, Y. and Gamage, A.S. (2016), "Examining Sri Lankan professional women's perceptions of their opportunities to undertake international careers: Implications for diversity amongst cross-cultural managers", International Journal of Cross Cultural Management, Vol. 16 No. 1, pp. 77-98.

Hutchings, K., Wilkinson, A. and Brewster, C. (2020), “Ageing academics do not retire - they just give up their administration and fly away: A study of older academic international business travellers", International Journal of Human Resource Management, https://doi.org/10.1080/09585192.2020.1754882

Kang, H., Shen, J., and Benson, J. (2015), "Not all expatriates are the same: non-traditional South Korean expatriates in China", The International Journal of Human Resource Management, Vol. 28 No. 13, pp. 1842-1865.

Kim, K. and Von Glinow M.A. (2017a), “Contextual determinants in disclosing one's stigmatized identity during expatriation”, Journal of Global Mobility, Vol. 5, pp.317-338.

Kim, K. and Von Glinow, M.A., (2017b), "Managing Non-traditional Human Capital in International Assignments: A Qualitative Analysis of the Talent and Innovation Gaps”, Kundu, $\mathrm{S}$ and Munjal, S. (Ed.), Human Capital and Innovation: Examining the role of globalization, Palgrave Macmillan, London. pp. 91-129.

Kraimer, M., Bolini, M., and Mead, B. (2016), “Themes in expatriate and repatriate research over four decades: What do we know and what do we still need to learn?", Annual Review of Organizational Psychology and Organizational Behaviour, Vol 3, pp. 83-109.

McNulty, Y. (2014), "Women as female breadwinners in non-traditional expatriate families: Status-reversal marriages, single parents, split families, and lesbian partnerships", Hutchings, K. and Michailova, S. (Eds.), Research Handbook on Women in International Management, Edward Elgar, Cheltenham, pp. 332-366. 
McNulty, Y. (2015), “Acculturating non-traditional expatriates: A case study of single parent, overseas adoption, split family, and lesbian assignees", International Journal of Intercultural Relations, Vol. 49, pp. 278-293.

McNulty, Y., and Brewster, C. (2017), “Theorizing the meaning(s) of 'expatriate': Establishing boundary conditions for business expatriates", The International Journal of Human Resource Management, Vol. 28 No. 1, pp. 27-61.

McNulty, Y., and Hutchings, K. (2016), "Looking for global talent in all the right places: A critical literature review of non-traditional expatriates", The International Journal of Human Resource Management, Vol, 27 No. 7, pp. 699-728.

McNulty, Y., McPhail, R., Inversi, C., Dundon, T. and Nechanska, E. (2018),” Employee voice mechanisms for lesbian, gay, bisexual and transgender expatriation: The role of EmployeeResource Groups (ERGs) and allies", International Journal of Human Resource Management, Vol. 29, pp.829-856.

McNulty, Y. and Selmer, J. (Eds.), (2017), Research Handbook of Expatriates, Edward Elgar, Cheltenham

McNulty, Y., Vance, C.M. and Fisher, K. (2017), "Beyond corporate expatriation - global mobility in the sports, religious, education and non-profit sectors", Journal of Global Mobility, Vol. 5 No. 2, pp. 110-122.

McPhail, R. (2017), “Lesbian, gay, bisexual, transgender and intersex (LGBTI) expatriates”, McNulty, Y. and Selmer, J. (Eds.), Research Handbook of Expatriates, Edward Elgar, Cheltenham, pp.202-217.

McPhail, R. and Fisher, R. (2015), "Lesbian and gay expatriates use of social media to aid acculturation", International Journal of Intercultural Relations IJIR, Vol. 49, pp.294. 
McPhail, R., McNulty, Y. and Hutchings, K. (2016), "Lesbian and gay expatriation: Opportunities, barriers, and challenges for global mobility", The International Journal of Human Resource Management, Vol. 27 No. 3, pp. 382-406.

Mercer (2021), Mobile workforce diversity and inclusion, available at https://mobilityexchange.mercer.com/, accessed $11^{\text {th }}$ January 2021.

Metcalfe, B., Hutchings, K. and Cooper, B. (2009), "Re-examining women's international management opportunities and experiences: A Middle Eastern perspective", Ibeh, K. and Davies, S. (Eds.). Contemporary Challenges to International Business, Palgrave-Macmillan, London, pp.232-247.

Michailova, S., and Hutchings, K. (2016), "Critiquing the marginalised place of research on women within international business: Where are we now and where should we be going?", critical perspectives on international business, Vol. 12 No. 4, pp.348-368.

Mizzi. R.C. (2014), “Troubling preparedness: investigating the (in)visibility of LGBT concerns within pre-departure orientations", Development in Practice, Vol. 24 No. 2, pp. 286-297, DOI: $10.1080 / 09614524.2014 .885493$

Mizzi, R.C. (2015), "Sexualities on the move: A comparison of the work experiences of gay male educators teaching overseas", Canadian Journal of Educational Administration and Policy, Vol. 173, available at https://cjc-rcc.ucalgary.ca/index.php/cjeap/article/view/42883, accessed $12^{\text {th }}$ January 2021.

Moeller, M. and Maley, J.F. (2018), "MNC Considerations in Identifying and Managing LGB Expatriate Stigmatization", International Journal of Management Reviews, Vol. 20, pp.325342.

Moher, D., Liberati, A., Tetzlaff, J., Altman, D. G. and the PRISMA Group. (2009), "Preferred reporting items for systematic reviews and meta-analyses: The PRISMA statement", PLoS Med. Vol. 6 No. 7. https://doi.org/10.1371/journal.pmed.1000097 
Muir, M., Wallace, M. and McMurray, D. (2014), "Women on the move: The self-initiated expatriate in China", Journal of Global Mobility, Vol. 2 No. 2, pp. 234-254.

Mutter, J., and Thorn, K. (2019), “The stay-behind family: living with contemporary global mobility", The International Journal of Human Resource Management, DOI: $10.1080 / 09585192.2019 .1640767$

O’Neil, K. (2016), “Australia. New rules limit accompanying family members”, available at https://www.linkedin.com/pulse/australia-new-rules-limit-accompanying-family-memberskent-o-neil, accessed 13th July 2021.

Özçelik, G., Haak-Saheem, W., Brewster, C., and McNulty, Y. (2019), "Hidden inequalities amongst the international workforce", In Nachmias, S. and Caven, V. (Eds.), Hidden Inequalities in the Workplace: A Guide to the Current Challenges, Issues and Business Solutions, Palgrave/ Springer, London, pp.221-252.

Paisley, V., and Tayar, M. (2016), "Lesbian, gay, bisexual and transgender (LGBT) expatriates: An intersectionality perspective", The International Journal of Human Resource Management, Vol. 27 No. 7, pp. 766-780.

Pereira, V., Malik, A., Howe-Walsh, L., Munjal, S. and Hirekhan, M. (2017), "Managing Yopatriates: A Longitudinal Study of Generation Y Expatriates in an Indian Multi-national Corporation”, Journal of International Management, Vol. 23, pp.151-165.

Pinto, L.H.F., Bader, B. and Schuster, T. (2017), "Dangerous settings and risky international assignments”, Journal of Global Mobility, Vol. 5 No. 4, pp. 342-347.

Rowson, T.S. (2015), “Transition to Retirement for Expatriates in the UAE: A Psychological Perspective", York Al-Karam, C. and Haque, A. (Ed.), Mental Health and Psychological Practice in the United Arab Emirates, Palgrave Macmillan, New York. pp.93-102.

Salamin, X., and Hanappi, D. (2014), "Women and international assignments: A systematic literature review exploring textual data by correspondence analysis", Journal of Global Mobility, Vol. 2 No. 3, pp. 343-374. 
Salleh, N. M. and Nankervis, A. (2017), "Non-Traditional Expatriate Assignments in the AsiaPacific: Characteristics \& Challenges", Human Resource Management Research, Vol. 5 No. 1, pp. 1-11.

Sante Fe Relocation (2021), Global Mobility Survey 2020/2021, available https://www.santaferelo.com/en/mobility-insights/global-mobility-survey/global-mobilitysurvey-2020-21-repurpose-challenging-change/ accessed $7^{\text {th }}$ January 2021.

Shaklee, B.D. (2007), "Focus on international schools: Serving students with learning disabilities", International Perspectives, Vol. 20, pp. 265-283.

Shortland, S. (2014), "Women expatriates: A research history”, Hutchings, K. and Michailova, S (Eds.), Research Handbook on Women in International Management, Edward Elgar, Chelteham, pp.18-46.

Sparkman, T.E. (2019), "Exploring the boundaries of diversity and inclusion in human resource development”, Human Resource Development Review, DOI: 10.1177/1534484319837030

Stasak, J-F. (2020), "Other/Otherness", International Encyclopedia of Human Geography, 2nd edition, Volume 10, pp.25-31, available at: https://doi.org/10.1016/B978-0-08-1022955.10204-525, accessed 27th June 2021.

Suen, Y.T. (2021), "Sexual minority expatriates as agent of change? How foreign same-sex couples won the recognition of same-sex relationship for immigration purposes in Hong Kong", Journal of Ethnic and Migration Studies, Vol. 47, No. 13, pp.2961-2978.

Sutton, R.I., and Straw, B.M. (1995), "What theory is not", Administrative Science Quarterly, Vol. 40 No. 3, pp. 371-384. 
Tharenou, P. (2009), “Women's self-initiated expatriation as a career option and its ethical issues", Journal of Business Ethics, Vol. 95, pp. 73-88. 
Total number of records identified

$(n=230)$

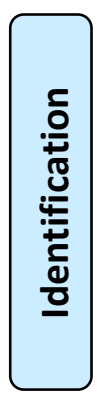

Records identified through database

searching

$(n=224)$
Additional records identified through other sources $(n=6)$

Records after duplicates (86) removed

$(n=144)$
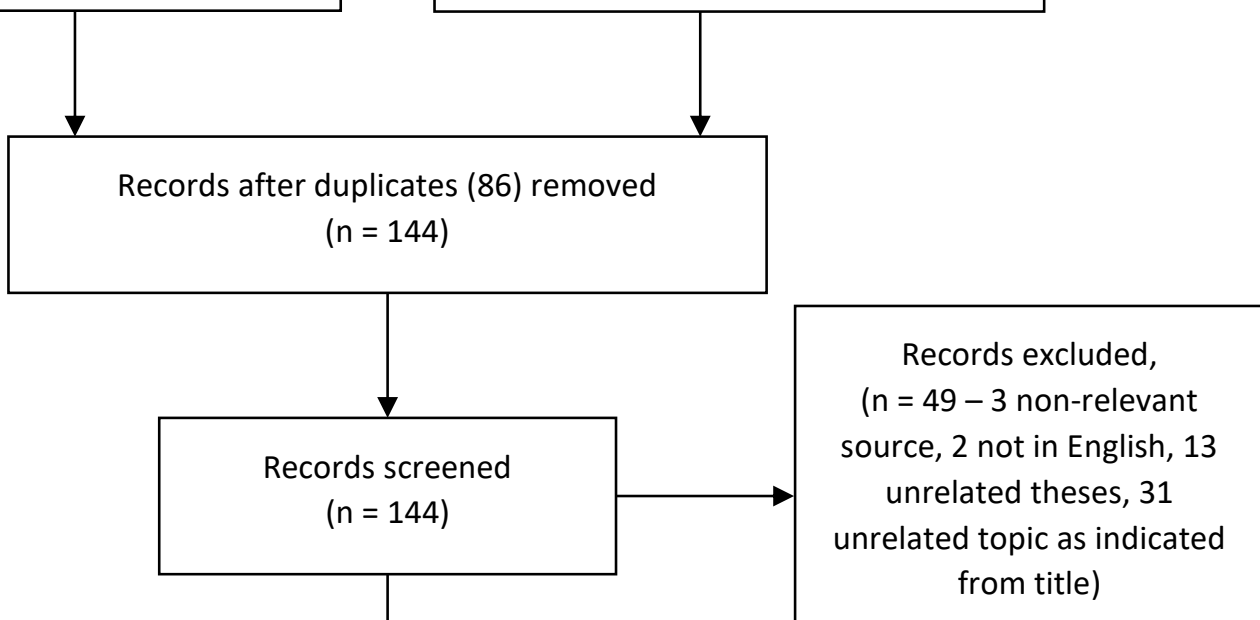

Full-text articles excluded, with reasons

( $n=72$ - unrelated topic or not sufficiently on topic)

Studies included in qualitative synthesis $(n=23)$

Figure 1: Flow diagram of systematic literature review search strategy (based on diagram developed by Moher et al., 2009). 


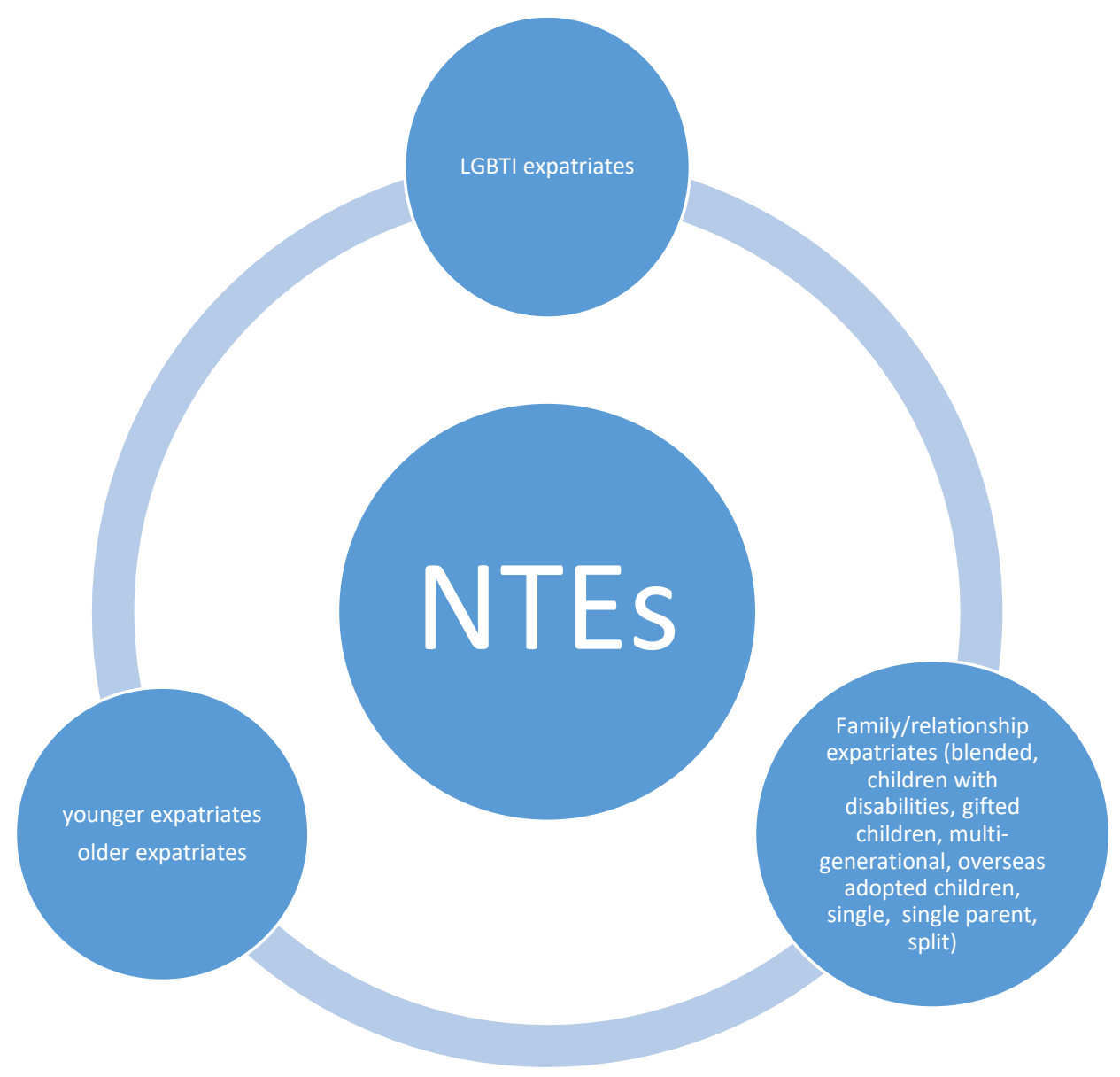

Figure 2: Categories of NTEs examined in systematic review of literature 2010-2020 


\section{NTE categories}

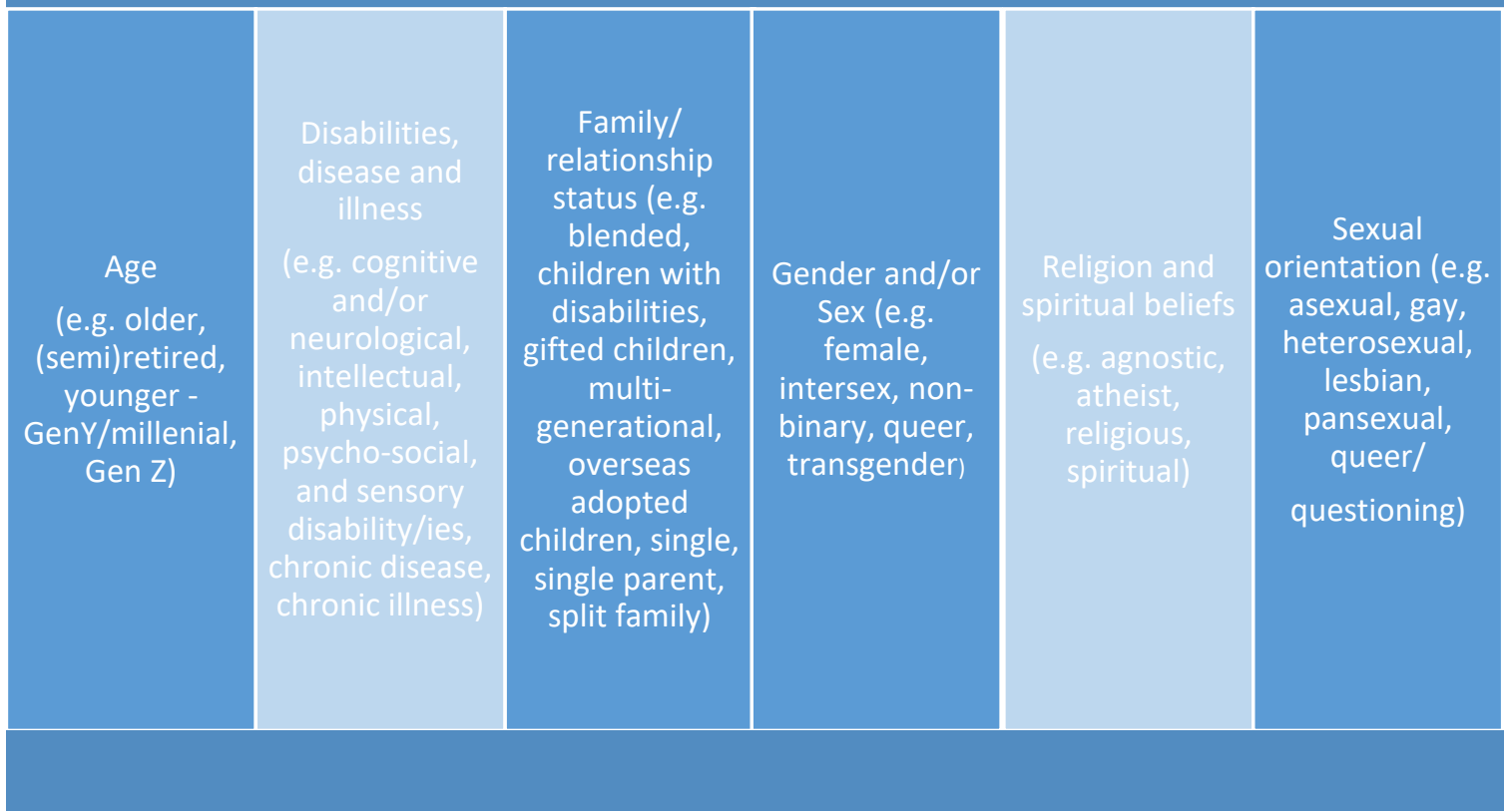

Figure 3: Categories of NTEs for future research

Note: Shaded categories have not been previously explored in NTE research 
Table 1: Summary of NTE publications 2010-2020

\begin{tabular}{|c|c|c|c|c|c|c|c|c|c|}
\hline Author/s & $\begin{array}{l}\text { Year of } \\
\text { publication }\end{array}$ & $\begin{array}{l}\text { Journal/ } \\
\text { publisher }\end{array}$ & $\begin{array}{l}\text { Google } \\
\text { Scholar } \\
\text { citations }\end{array}$ & $\begin{array}{l}\text { Country/ies } \\
\text { of author/s, } \\
\text { institutional } \\
\text { affiliation }\end{array}$ & $\begin{array}{l}\text { Type/s of NTE } \\
\text { examined }\end{array}$ & $\begin{array}{l}\text { Methodological } \\
\text { approach }\end{array}$ & $\begin{array}{l}\text { Cross-sectional } \\
\text { or longitudinal } \\
\text { (empirical } \\
\text { papers only) }\end{array}$ & $\begin{array}{l}\text { Data collected } \\
\text { (empirical } \\
\text { papers only) }\end{array}$ & $\begin{array}{l}\text { Theory/ies } \\
\text { and/or } \\
\text { research } \\
\text { used }\end{array}$ \\
\hline $\begin{array}{l}\text { Clark and } \\
\text { Altman }\end{array}$ & 2016 & IJHRM & 19 & $\begin{array}{l}\text { UK } \\
\text { France }\end{array}$ & $\begin{array}{l}\text { Multi-generational } \\
\text { expatriate family } \\
\text { Expatriate children } \\
\text { with disability/ies }\end{array}$ & Qualitative & Longitudinal & $\begin{array}{l}4 \text { interviewees } \\
\text { (interviewed } \\
\text { multiple times } \\
\text { following an } \\
\text { initial survey) }\end{array}$ & $\begin{array}{l}\text { Liquid modernity } \\
\text { Social ties/social } \\
\text { networks }\end{array}$ \\
\hline $\begin{array}{l}\text { Crowley-Henry } \\
\text { and Collins }\end{array}$ & 2017 & Edward Elgar & 3 & Ireland & Younger expatriates & Qualitative & Cross-sectional & 6 interviews & $\begin{array}{l}\text { Younger } \\
\text { employees } \\
\text { research }\end{array}$ \\
\hline Gedro & 2010 & HRDR & 79 & USA & Lesbian expatriates & Conceptual & N/A & N/A & LGBT research \\
\hline $\begin{array}{l}\text { Gedro, Mizzi, } \\
\text { Rocco and } \\
\text { Van Loo }\end{array}$ & 2013 & HDRI & 57 & $\begin{array}{l}\text { USA } \\
\text { Canada } \\
\text { USA } \\
\text { Greece }\end{array}$ & LGBT expatriates & Qualitative & Longitudinal & $\begin{array}{l}3 \text { auto- } \\
\text { ethnographic } \\
\text { stories }\end{array}$ & LGBT research \\
\hline Guttormsen & 2018 & SJM & 12 & Norway & $\begin{array}{l}\text { NTEs across } \\
\text { categories }\end{array}$ & Conceptual & N/A & N/A & $\begin{array}{l}\text { Field/relationality } \\
\text { theory }\end{array}$ \\
\hline $\begin{array}{l}\text { Hutchings and } \\
\text { McNulty }\end{array}$ & Forthcoming & Edward Elgar & 0 & $\begin{array}{l}\text { Australia } \\
\text { Singapore }\end{array}$ & $\begin{array}{l}\text { Split family } \\
\text { expatriates }\end{array}$ & Qualitative & Cross-sectional & $\begin{array}{l}4 \text { interviews } \\
\text { ( } 2 \text { couples })\end{array}$ & $\begin{array}{l}\text { Family systems } \\
\text { theory } \\
\text { Stress theory }\end{array}$ \\
\hline $\begin{array}{l}\text { Hutchings, } \\
\text { Wilkinson and } \\
\text { Brewster }\end{array}$ & 2020 & IJHRM & 1 & $\begin{array}{l}\text { Australia } \\
\text { UK }\end{array}$ & Older expatriates & Qualitive & Cross-sectional & 23 interviews & Identity theory \\
\hline $\begin{array}{l}\text { Kim and Von } \\
\text { Glinow }\end{array}$ & $2017 \mathrm{a}$ & JGM & 8 & USA & $\begin{array}{l}\text { Lesbian and gay } \\
\text { expatriates }\end{array}$ & Qualitative & Cross-sectional & $\begin{array}{l}\text { interviews } \\
\text { (preceded by a } \\
\text { questionnaire) }\end{array}$ & $\begin{array}{l}\text { Social identity } \\
\text { theory } \\
\text { Self- } \\
\text { categorisation } \\
\text { theory }\end{array}$ \\
\hline $\begin{array}{l}\text { Kim and Von } \\
\text { Glinow }\end{array}$ & $2017 b$ & Palgrave & 0 & USA & $\begin{array}{l}\text { Lesbian and gay } \\
\text { expatriates }\end{array}$ & Qualitative & Cross-sectional & 4 interviews & $\begin{array}{l}\text { Social identity } \\
\text { theory }\end{array}$ \\
\hline McNulty & 2014 & Edward Elgar & 34 & Singapore & $\begin{array}{l}\text { Status-reversal } \\
\text { expatriates }\end{array}$ & Qualitative & Cross-sectional & 4 interviews & $\begin{array}{l}\text { Family systems } \\
\text { theory }\end{array}$ \\
\hline
\end{tabular}




\begin{tabular}{|c|c|c|c|c|c|c|c|c|c|}
\hline & & & & & $\begin{array}{l}\text { Single parent } \\
\text { expatriates } \\
\text { Split family } \\
\text { expatriates } \\
\text { Lesbian expatriates }\end{array}$ & & & & \\
\hline McNulty & 2015 & IJIR & 43 & Singapore & $\begin{array}{l}\text { Single parent } \\
\text { expatriates } \\
\text { Expatriates with } \\
\text { overseas adopted } \\
\text { children }\end{array}$ & Qualitative & Cross-sectional & 4 interviews & $\begin{array}{l}\text { Acculturation/adj } \\
\text { ustment research }\end{array}$ \\
\hline $\begin{array}{l}\text { McNulty and } \\
\text { Hutchings }\end{array}$ & 2016 & IJHRM & 55 & $\begin{array}{l}\text { Singapore } \\
\text { Australia }\end{array}$ & $\begin{array}{l}\text { NTEs across } \\
\text { categories }\end{array}$ & $\begin{array}{l}\text { Critical } \\
\text { literature review }\end{array}$ & N/A & N/A & $\begin{array}{l}\text { Various } \\
\text { expatriate/expatri } \\
\text { ation research }\end{array}$ \\
\hline $\begin{array}{l}\text { McNulty, } \\
\text { McPhail, } \\
\text { Inversi, } \\
\text { Dundon and } \\
\text { Nechanska }\end{array}$ & 2018 & IJHRM & 21 & $\begin{array}{l}\text { Singapore } \\
\text { Australia } \\
\text { UK } \\
\text { UK } \\
\text { Ireland } \\
\end{array}$ & LGBT expatriates & Qualitative & Cross-sectional & 20 interviews & $\begin{array}{l}\text { Stereotype threat } \\
\text { theory }\end{array}$ \\
\hline McPhail & 2017 & Edward Elgar & 2 & Australia & LGBTI expatriates & $\begin{array}{l}\text { Literature } \\
\text { review }\end{array}$ & N/A & N/A & LGBT research \\
\hline $\begin{array}{l}\text { McPhail and } \\
\text { Fisher }\end{array}$ & 2015 & IJIR & 19 & $\begin{array}{l}\text { Australia } \\
\text { Australia }\end{array}$ & $\begin{array}{l}\text { Lesbian and gay } \\
\text { expatriates }\end{array}$ & Qualitative & Cross-sectional & 21 interviews & $\begin{array}{l}\text { Acculturation } \\
\text { research } \\
\text { Social capital } \\
\text { theory }\end{array}$ \\
\hline $\begin{array}{l}\text { McPhail and } \\
\text { McNulty }\end{array}$ & 2015 & EJIM & 30 & $\begin{array}{l}\text { Australia } \\
\text { Singapore }\end{array}$ & $\begin{array}{l}\text { Lesbian and gay } \\
\text { expatriates }\end{array}$ & Qualitative & Cross-sectional & $\begin{array}{l}4 \text { interviews } \\
9 \text { online surveys } \\
\text { (using the same } \\
\text { interview } \\
\text { questions) }\end{array}$ & $\begin{array}{l}\text { Global talent } \\
\text { management } \\
\text { research }\end{array}$ \\
\hline
\end{tabular}




\begin{tabular}{|c|c|c|c|c|c|c|c|c|c|}
\hline $\begin{array}{l}\text { McPhail, } \\
\text { McNulty and } \\
\text { Hutchings }\end{array}$ & 2016 & IJHRM & 74 & $\begin{array}{l}\text { Australia } \\
\text { Singapore } \\
\text { Australia } \\
\end{array}$ & $\begin{array}{l}\text { Lesbian and gay } \\
\text { expatriates }\end{array}$ & Qualitative & Cross-sectional & 20 interviews & $\begin{array}{l}\text { Social capital } \\
\text { theory }\end{array}$ \\
\hline Mizzi & 2014 & DIP & 20 & Canada & Gay expatriates & Qualitative & Cross-sectional & $\begin{array}{l}8 \text { interviews } \\
\text { Documentary } \\
\text { analysis }\end{array}$ & LGBT research \\
\hline Mizzi & 2015 & CJEAP & 0 & Canada & Gay expatriates & Qualitative & Cross-sectional & $\begin{array}{l}\text { Project one }-8 \\
\text { interviews } \\
\text { Project two }-5 \\
\text { interviews }\end{array}$ & LGBT research \\
\hline $\begin{array}{l}\text { Moeller and } \\
\text { Maley }\end{array}$ & 2018 & IJMR & 9 & $\begin{array}{l}\text { Australia } \\
\text { Australia }\end{array}$ & $\begin{array}{l}\text { Lesbian, gay and bi- } \\
\text { sexual expatriates }\end{array}$ & Conceptual & N/A & N/A & $\begin{array}{l}\text { Organisational } \\
\text { legitimacy theory }\end{array}$ \\
\hline $\begin{array}{l}\text { Paisley and } \\
\text { Tayar }\end{array}$ & 2016 & IJHRM & 74 & $\begin{array}{l}\text { Australia } \\
\text { Australia }\end{array}$ & LGBT expatriates & Conceptual & N/A & N/A & $\begin{array}{l}\text { Social } \\
\text { constructivist } \\
\text { intersectionality } \\
\text { theory }\end{array}$ \\
\hline $\begin{array}{l}\text { Pereira, } \\
\text { Malik, } \\
\text { Howe-Walsh, } \\
\text { Munjal and } \\
\text { Hirekhan }\end{array}$ & 2017 & JIM & 15 & $\begin{array}{l}\text { UAE } \\
\text { Australia } \\
\text { UK } \\
\text { UK } \\
\text { UK }\end{array}$ & Younger expatriates & Qualitative & Longitudinal & $\begin{array}{l}22 \text { interviews } \\
3 \text { focus groups } \\
\text { with } 15 \\
\text { participants }\end{array}$ & $\begin{array}{l}\text { Cross-cultural } \\
\text { adjustment } \\
\text { research }\end{array}$ \\
\hline Suen & 2021 & JEMS & 3 & $\begin{array}{l}\text { Hong Kong, } \\
\text { PRC }\end{array}$ & $\begin{array}{l}\text { Lesbian and gay } \\
\text { expatriates }\end{array}$ & Qualitative & Longitudinal & $\begin{array}{l}26 \text { interviews } \\
\text { (13 couples) }\end{array}$ & Framing theory \\
\hline
\end{tabular}

Note: Column two provides details of the country/ies in which the author/s' university/institution is based (at the time of publication). Though this may also be the country of origin and/or country of residence of the author/s, in many cases it will not be, and the intention is only to show the countries in which the author/s are based and does not necessarily relate to author/s' nationality or ethnicity.

Note: Google Scholar citations were accessed 30 June 2021. 